\title{
Prolonged Effects of Silver Nanoparticles on p53/p21 Pathway-Mediated Proliferation, DNA Damage Response, and Methylation Parameters in HT22 Hippocampal Neuronal Cells
}

\author{
Jennifer Mytych $^{1} \cdot$ Jacek Zebrowski $^{2} \cdot$ Anna Lewinska $^{3} \cdot$ Maciej Wnuk $^{1}$
}

Received: 17 October 2015 / Accepted: 5 January 2016/Published online: 3 February 2016

(C) The Author(s) 2016. This article is published with open access at Springerlink.com

\begin{abstract}
It is widely accepted that silver nanoparticles (AgNPs) are toxic to biological systems. However, little is known about their actions at molecular level and the cytophysiological effects after AgNP removal. As nanoparticles are suggested a promising tool to transport drugs to the brain for use in neurological conditions, we used HT22 mouse hippocampal neuronal cells as a model to study AgNPmediated effects after their removal from the cell culture medium. We selected a relatively low concentration of AgNPs, $5 \mu \mathrm{g} / \mathrm{ml}$, treated the cells for $48 \mathrm{~h}$, and evaluated AgNPinduced cytophysiological effects after $96 \mathrm{~h}$ of AgNP removal. AgNP removal did not result in cytotoxicity. In contrast, AgNPs modulated HT22 cell cycle and proliferation and induced oxidative stress and 53BP1 recruitment, which were accompanied by elevated levels of p53 and p21. AgNPassociated diminution in lamin B1 pools did not significantly affect the structure of the nucleus. No disruption in F-actin dynamics was observed upon AgNP treatment. Moreover, we showed for the first time that AgNPs stimulated changes in DNA methylation: the augmentation in 5-methylcytosine (5-mC) and DNMT1, DNMT2, DNMT3a, and DNMT3b
\end{abstract}

Anna Lewinska and Maciej Wnuk contributed equally to this work.

Anna Lewinska

alewinska@o2.pl

$\triangle$ Maciej Wnuk

mawnuk@gmail.com

1 Department of Genetics, University of Rzeszow, Rejtana 16C, 35-959 Rzeszow, Poland

2 Department of Plant Physiology, University of Rzeszow, Werynia 502, 36-100 Kolbuszowa, Poland

3 Department of Biochemistry and Cell Biology, University of Rzeszow, Zelwerowicza 4, 35-601 Rzeszow, Poland levels were observed. The upregulation of DNMT2 may be a part of cellular stress response to AgNP treatment. Taken together, AgNP removal resulted in p53/p21-mediated inhibition of cell proliferation, oxidant-based DNA damage response, and changes in DNA methylation patterns, which suggests that more attention should be paid to the possible outcomes in individuals exposed to nano-sized biomaterials.

Keywords Silver nanoparticles $\cdot$ HT22 cells $\cdot$ DNA methylation $\cdot$ DNMTs $\cdot$ Oxidative stress

\section{Introduction}

Silver-nanoparticle-based materials with potent antimicrobial activities and unique physico-chemical properties are widely used in electronics, biosensing, clothing, food industry, paints, sunscreens, cosmetics, and medical devices [1-3]. Due to numerous applications of silver nanoparticles (AgNPs) in biomedical sciences, a comprehensive analysis of AgNP effects both short- and long-term actions on biological systems is needed.

It has been repeatedly reported that AgNPs induced toxicity both in vitro and in vivo [4-7]. AgNPs affected a plethora of normal and cancer cell lines and AgNP toxicity was accompanied by oxidative stress: increased production of reactive oxygen species (ROS) and/or glutathione depletion and decreased activity of antioxidant enzymes, which may contribute to decreased proliferation, genotoxic events, and/or apoptosis [4, 5, 8-14]. Despite some controversies on the mechanisms of action of AgNPs [14-16], AgNP toxicity is suggested to be independent of the toxicity of silver ions [12]. AgNPs and silver ions were also shown to trigger two different cellular responses as estimated using quantitative proteomics [17]. 
AgNPs may affect the global gene expression [18-20], but the mechanisms underlying such regulation are largely unknown. After treatment of human lung A549 and cervical HeLa cancer cells with AgNPs, the expression profiles of more than 1000 genes were modulated, e.g., encoding metallothioneins, heat shock proteins, and histone proteins [18, 19]. Moreover, AgNP-mediated defective DNA repair, proliferation arrest, and inflammatory response in IMR-90 human lung fibroblasts and U251 glioblastoma cells may be a consequence of AgNPinduced changes in the gene expression patterns, such as the upregulation of DNA damage response genes $(G A D D 45)$ and the downregulation of cell cycle progression genes encoding cyclin $\mathrm{B}$ and cyclin $\mathrm{E}$, and involved in DNA damage repair (XRCC1, XRCC3, FEN1, RAD51C, RPA1) [20]. AgNPs, when used at non-cytotoxic concentrations $(<0.5 \mu \mathrm{g} / \mathrm{ml})$, may also promote some adverse effects by affecting the expression of genes associated with cell cycle progression and apoptosis in human hepatoma cells (HepG2) [7]. Data on the mechanisms of AgNP-mediated regulation of the gene expression and protein translation are limited [21]. More recently, AgNP-induced MTIF (metallothionein $1 \mathrm{~F}$ ) and TRIB3 (tribbles homolog 3) expressions have been reported to be regulated by miR-219-5p in Jurkat $\mathrm{T}$ cells [21], which suggest the involvement of an epigenetic mechanism.

Little is known on prolonged effects of low, non-cytotoxic doses of AgNPs in the brain tissue. AgNP-induced dopaminergic neurotoxicity has been revealed in PC-12 rat neuronal cell line $[22,23]$. AgNPs also caused a significant stress response in the growing human embryonic neural precursor cells (HNPCs) by simultaneously affecting cell proliferation and apoptotic cell death [24]. AgNP-mediated calcium dysregulation and reactive oxygen species (ROS) formationbased response have been observed in a mixed primary cell model (neurons, astrocytes, and a minor proportion of oligodendrocytes) [25]. AgNP-induced calcium imbalance, destabilization of mitochondrial function, and ROS production have also been reported in primary cultures of cerebellar granule cells [26]. More recently, sublethal concentrations of AgNPs have been found to disrupt actin dynamics in cultured adult neural stem cells [27]. However, data on the cytophysiological effects after AgNP removal from biological systems are lacking, especially AgNP-mediated effects on neural cell epigenome.

HT22 cells are considered as a sensitive model for monitoring cellular responses to oxidative stress due to the lack of ionotropic glutamate receptors [28] and are widely used to study the mechanisms of neurotoxicity and to search for neuroprotective compounds [29-31]. In the present study, we used HT22 mouse hippocampal neuronal cell line to evaluate prolonged effects of low concentration of AgNPs $(5 \mu \mathrm{g} / \mathrm{ml})$; especially, we were interested if cell proliferation, redox state, DNA damage response, and methylation parameters may be affected after AgNP removal.

\section{Materials and Methods}

\section{Chemicals}

Dihydroethidium and MitoSOX ${ }^{\mathrm{TM}}$ were purchased from Molecular Probes (Leiden, Netherlands) and phosphate-buffered saline (PBS) was obtained from (Gibco, Invitrogen Corporation, Grand Island, NY, USA). All other reagents, if not mentioned otherwise, were purchased from Sigma (Poznan, Poland) and were of analytical grade.

\section{Nanoparticle Size and Zeta Potential Measurements}

Silver nanoparticles (AgNPs), <100-nm particle size (TEM; 758329, Sigma, Poznan, Poland), were characterized. Both particle size and the zeta potential of AgNPs dispersed in water were measured using ZetaSizer Nano ZS (Mavern Instruments, Mavern, UK) equipped with a 633-nm laser. The AgNP concentration and $\mathrm{pH}$ were adjusted to values characteristic for suspension of the particles in culture medium used. The dispersion was measured at $25{ }^{\circ} \mathrm{C}$. The particle size distribution was assessed in a dynamic light scattering (DLS) mode on the base of a correlation function analysis for scattering angle of $173^{\circ}$ (non-invasive back-scatter technology). The refraction index for silver material was assumed equal to 0.135 . Prior to measurements, the samples were sonicated for $30 \mathrm{~min}$. Five replicates were performed per measurement. The zeta potential of AgNPs in the medium $(\mathrm{pH}=7.2)$ was assessed on the basis of Laser Doppler Velocimetry (LDV) taking into account their electrophoretic mobility. The Smoluchowski approximation was chosen for zeta potential evaluation. Three replicates were performed per measurement, each at hundred runs.

\section{Nanoparticle Agglomeration Analysis}

Atomic force microscopy (AFM) was used to elucidate the tendency of AgNPs to agglomerate in DMEM culture medium and the susceptibility of serum components to agglomerate in the presence of AgNPs. The appropriate suspensions were deposited on atomic flat mica substrate (V1 grade, Ted Pella Inc., USA) and allowed to dry under $\mathrm{N}_{2}$ stream. AFM height sensor images were collected in Peak Force Tapping mode using Bioscope Catalyst II atomic force microscope equipped with Nanoscope V controller (Veeco, Santa Barbara, CA, USA). AFM topography imaging was performed in the air using Bruker silicon scanasyst-flu$\mathrm{id}+$ probes. Images were processed and analyzed for nanoparticle height by means of Nanoscope Analysis (v. $1.40 \mathrm{R} 3 \mathrm{sr} 5$, Bruker) software. 


\section{Protein Corona Formation Analysis}

The ability of the serum proteins to bind AgNPs was evaluated using sodium dodecyl sulfate polyacrylamide gel electrophoresis (SDS-PAGE) and Coomassie staining. Briefly, DMEM medium containing $10 \%$ FBS was incubated with $5 \mu \mathrm{g} / \mathrm{ml}$ AgNPs at $37{ }^{\circ} \mathrm{C}$ for $48 \mathrm{~h}$. AgNP-treated medium was then centrifuged $\left(15,000 \mathrm{rpm}, 15 \mathrm{~min}, 4{ }^{\circ} \mathrm{C}\right)$, washed three times with ice-cold PBS $\left(15,000 \mathrm{rpm}, 15 \mathrm{~min}, 4^{\circ} \mathrm{C}\right)$, and added with $25 \mu \mathrm{l}$ of PBS and $25 \mu \mathrm{l}$ of $2 \times$ Laemmli buffer. The samples were then vigorously mixed, boiled at $95{ }^{\circ} \mathrm{C}$ for $5 \mathrm{~min}$, and centrifuged (15,000 rpm, $15 \mathrm{~min})$. The supernatants were collected and resolved on $10 \%$ SDS-PAGE. The gel was stained using $0.25 \%$ Coomassie Brilliant Blue R-250 in $45 \%$ methanol and $10 \%$ acetic acid for $30 \mathrm{~min}$, washed twice with water for $10 \mathrm{~min}$, and de-stained using $45 \%$ methanol and $10 \%$ acetic acid solution for $1 \mathrm{~h}$.

\section{Cell Culture}

HT22 mouse hippocampal neuronal cell line was a generous gift from Prof. Michal Wozniak and Dr. Magdalena Gorska (Medical University of Gdansk, Gdansk, Poland). Cells (3000 cells $/ \mathrm{cm}^{2}$ ) were cultured at $37{ }^{\circ} \mathrm{C}$ in Dulbecco's modified Eagle's medium (DMEM) supplemented with $10 \%$ fetal calf serum (FCS) and antibiotic and antimycotic mix solution (100 U/ml penicillin, $0.1 \mathrm{mg} / \mathrm{ml}$ streptomycin, and $0.25 \mu \mathrm{g} / \mathrm{ml}$ amphotericin B) in a humidified atmosphere in the presence of $5 \% \mathrm{CO}_{2}$ until they reached confluence. Typically, cells were passaged by trypsinization and maintained in DMEM. The freshly prepared stock solution of AgNPs $(10 \mathrm{mg} / \mathrm{ml}$ in sterile PBS) was added to HT22 cells to obtain final concentrations ranging from 1 to $20 \mu \mathrm{g} / \mathrm{ml}$.

\section{Cytotoxicity, Cell Proliferation, and Cell Cycle Analysis}

After 48-h treatment with AgNPs $(1-20 \mu \mathrm{g} / \mathrm{ml})$, cytotoxic/ cytostatic potential was estimated using MTT assay [32], cell proliferation was established using bromodeoxyuridine (BrdU) incorporation assay [33], and DNA-content-based cell cycle analysis was conducted using imaging cytometry [34]. A concentration reflecting $\mathrm{IC}_{50}$ value (MTT assay), $5 \mu \mathrm{g} / \mathrm{ml}$, was selected to study prolonged effects of AgNPs. Briefly, HT22 cells were incubated with $5 \mu \mathrm{g} / \mathrm{ml} \mathrm{AgNPs} \mathrm{for} 48 \mathrm{~h}$, washed three times with PBS, and cultured in AgNP-free medium for up to $144 \mathrm{~h}$ ( $96 \mathrm{~h}$ after AgNP removal). Every $48 \mathrm{~h}$, the cells were washed three times with PBS and the medium was replaced by a fresh one. Cytotoxicity, cell cycle, and cell proliferation (DNA synthesis) were then evaluated. Cytotoxicity was assayed using acridine orange-ethidium bromide staining [35]. HT22 cells were washed twice with PBS, and a mixture of acridine orange $(100 \mu \mathrm{g} / \mathrm{ml}$ in PBS $)$ and ethidium bromide $(100 \mu \mathrm{g} / \mathrm{ml}$ in PBS) at a volume ratio of $1: 1$ was added to the cells, which were then analyzed with an Olympus BX61 fluorescence microscope equipped with a DP72 CCD camera and Olympus CellF software. Live/dead cell analysis was conducted according to the principle that acridine orange stained live cells green, while ethidium bromide stained dead cells red to orange. A total of 200 cells were counted.

For DNA-content-based cell cycle analysis [34], HT22 cells were stained with Hoechst $33342(2.5 \mu \mathrm{g} / \mathrm{ml})$ and digital cell images were captured with an In Cell Analyzer 2000 (GE Healthcare, UK) equipped with a high-performance CCD camera. DNA content of a total of 200 cells was analyzed using ImageJ software and DNA Cell Cycle plug-in from MBF Collection (http://imagej.net/plugins/mbf/mbf-plugins.zip).

For DNA synthesis, BrdU assay was used [33]. BrdU was added to the medium $(10 \mu \mathrm{M})$ for $24 \mathrm{~h}$ and was detected using primary antibody against BrdU (Becton Dickinson, Poland). A total of 200 cells were analyzed under a fluorescence microscope, and the $\%$ of BrdU positive cells was calculated. Moreover, cells were counted using a Bürker chamber.

\section{Silver Ion and Serum Effects}

The effects of $\mathrm{AgNO}_{3}$ on cell viability were also evaluated. HT22 cells were cultured with $\mathrm{AgNO}_{3}(1-20 \mu \mathrm{g} / \mathrm{ml})$ for $48 \mathrm{~h}$ and MTT assay was conducted. Moreover, to evaluate the effect of silver ion release from AgNPs, DMEM medium was pre-incubated with $\mathrm{AgNPs}(5 \mu \mathrm{g} / \mathrm{ml})$ for $48 \mathrm{~h}$, centrifuged $(15,000 \mathrm{rpm}, 15 \mathrm{~min})$, and used as a cell culture medium. HT22 cells were also cultured in a serum-free medium in the presence of $5 \mu \mathrm{g} / \mathrm{ml} \mathrm{AgNPs}$ to establish serum-associated effect on AgNP-mediated cell viability (MTT assay).

\section{Morphology, F-actin, and Nucleus Labeling}

Cell morphology was monitored using an Olympus BX71 inverted microscope equipped with a DP72 CCD camera and a computer image analysis system CellB. Intracellular localization of AgNPs after 48-h treatment and after AgNP removal was evaluated using Nomarski microscopy. To analyze AgNP-mediated changes in nucleus, HT22 cells were fixed [32] and DNA was visualized using Hoechst 33342 staining. F-actin was stained using Alexa Fluor ${ }^{\circledR} 488$ Phalloidin (a high-affinity filamentous actin, F-actin, probe conjugated to green fluorescent Alexa Fluor ${ }^{\circledR} 488$ dye) according to manufacturer's instructions (Life Technologies). Additionally, lamin B1 was immunodetected using lamin B1 antibody (1:100, Life Technologies) and secondary antibody conjugated with Texas red (1:1000, Life Technologies). Digital cell images were captured with an Olympus BX61 fluorescence microscope equipped with a DP72 CCD camera and Olympus CellF software. To analyze nuclear lamin B1 content, ImageJ software http://rsbweb.nih.gov/ij/ was used. We evaluated the integrated fluorescence density (red channel), 
which is the sum of all pixel values within the marked area of each nucleus analyzed and equivalent to the product of area and mean gray value. The integrated fluorescence density is presented in relative fluorescence units (RFUs). A total of 2000 cells were analyzed.

\section{Oxidative Stress Parameters}

Intracellular reactive oxygen species (ROS) production and superoxide production, both total and mitochondrial, were measured using $2^{\prime}, 7^{\prime}$-dichlorodihydrofluorescein diacetate $\left(\mathrm{H}_{2} \mathrm{DCF}-\mathrm{DA}\right)$, dihydroethidium, and MitoSOX ${ }^{\mathrm{TM}}$, respectively, as described elsewhere [32].

\section{BP1 Immunostaining}

For 53BP1 immunostaining, interphase nuclei were used. HT22 cells were fixed with $3.7 \%$ formaldehyde containing $0.1 \%$ Triton X-100 in PBS for 20 min and incubated with $1 \%$ bovine serum albumin (BSA) in phosphate-buffered saline containing $0.25 \%$ Triton X-100 (PBST) at room temperature for $30 \mathrm{~min}$. After washing with PBST, the cells were incubated with a rabbit polyclonal antibody against 53BP1 (Novus Biologicals, Poland; diluted 1:200 in PBST-BSA (PBST containing $1 \% \mathrm{BSA}$ )) overnight at $4{ }^{\circ} \mathrm{C}$, and with a FITC-conjugated, secondary polyclonal antibody against rabbit IgG (BD Biosciences, Germany; diluted 1:200 in PBST-BSA) at room temperature for $1 \mathrm{~h}$. Nuclei were visualized with Hoechst 33342. Digital cell images were captured with an In Cell Analyzer 2000 (GE Healthcare, UK) equipped with a high-performance CCD camera. The cells with $0,1-3,4-9$, and more than 10 53BP1 foci (48-h treatment with $1-20 \mu \mathrm{g} / \mathrm{ml}$ AgNPs) or cells with $0,1,2$, and 3 53BP1 foci (96 h after AgNP removal) were scored $(\%)$.

\section{Western Blotting}

Whole cell protein extracts were prepared according to Mytych et al. [32]. Polivinylidene difluoride (PVDF) membrane was incubated with one of the primary antibodies: anti-p21 (1:100), anti-p53 (1:1000), anti-lamin B1 (1:1000), antiDNMT2 (1:500), and anti- $\beta$-actin (1:1000) (Abcam, Thermo Scientific and Novus Biologicals) and secondary antibody conjugated with HRP (1:80,000; Sigma). The respective proteins were detected using the ECL Plus system (GE Healthcare), according to the manufacturer's instructions. The data represent the relative density normalized to $\beta$-actin [32].

\section{RNA Status}

RNA was isolated using RNeasy Mini Kit (Qiagen, USA). RNA chip electrophoresis was performed with Experion ${ }^{\mathrm{TM}}$ Automated Electrophoresis System and Experion ${ }^{\mathrm{TM}}$ RNA
Std-Sens Analysis Kit (Biorad, Germany). Total RNA level (pg) was calculated per cell and RNA integrity as a $28 \mathrm{~S} / 18 \mathrm{~S}$ rRNA ratio [33].

\section{Methylation Parameters}

The levels of 5-methylcytosine (5-mC), and DNA methyltransferases 1, 3a, and 3b (DNMT1, DNMT3a and DNMT3b) were measured using MethylFlash ${ }^{\mathrm{TM}}$ Methylated DNA Quantification Kit, EpiQuik $^{\mathrm{TM}}$ DNMT1 Assay Kit, EpiQuik ${ }^{\mathrm{TM}}$ DNMT3a Assay Kit, and EpiQuik ${ }^{\mathrm{TM}}$ DNMT3b Assay Kit, respectively, (Epigentek, Farmingdale, NY, USA) according to the manufacturer's instructions. The calculations were made on the basis of the standard curves obtained for positive control solutions and 5-mC content is presented as nanograms of 5-mC, and DNMT1, DNMT3a, and DNMT3b levels as ng/ mg protein.

\section{Statistical Analysis}

The results represent the mean \pm SD from at least three independent experiments. The obtained data conform the ANOVA assumptions as evaluated using Shapiro-Wilk normality test and Levene test for the equality of variances. Statistical significance was assessed by one-way ANOVA using GraphPad Prism 5, with Dunnett's multiple comparison test.

\section{Results}

As AgNPs were commercially purchased, we initially analyzed the AgNP size, dispersion stability, tendency to agglomerate in the cell culture medium, and protein corona formation (Fig. 1).

The hydrodynamic size distribution analysis of AgNPs at a concentration of $5 \mu \mathrm{g} / \mathrm{ml}$ showed a mean value of size equal to $8.05 \pm 0.88 \mathrm{~nm}$. The polydispersity index of the system was 0.66 and thus below critical value of 0.7 , indicating suitability of the samples for DLS-based analysis and mono-size particle dispersion assay. Typical size distribution patterns by volume (a) and number (b) are shown in Fig. 1 in Panel I. A prominent peak at about $8.7 \mathrm{~nm}$ and very low, broad peak around value of $90 \mathrm{~nm}$ were observed (Fig. 1, Panel I, a). Volumetric fraction of the particles above $20 \mathrm{~nm}$, which may be considered as AgNP agglomerates, was $3.2 \%$. However, the transformation of these data into size distribution by number (Fig. 1, Panel I, b) indicated that almost $100 \%$ of particles in sample are of the size around $7.54 \pm 1.77 \mathrm{~nm}$, while localization of the peak corresponding to the fraction of potentially clustered particles was shifted to $45.4 \pm 16.2 \mathrm{~nm}$. This confirms that the particle fraction, which may be considered as agglomerates, is rather marginal. The dynamic light scattering (DLS) analysis showed variability of AgNPs in size ranging from 
Panel I

Size distribution by volume

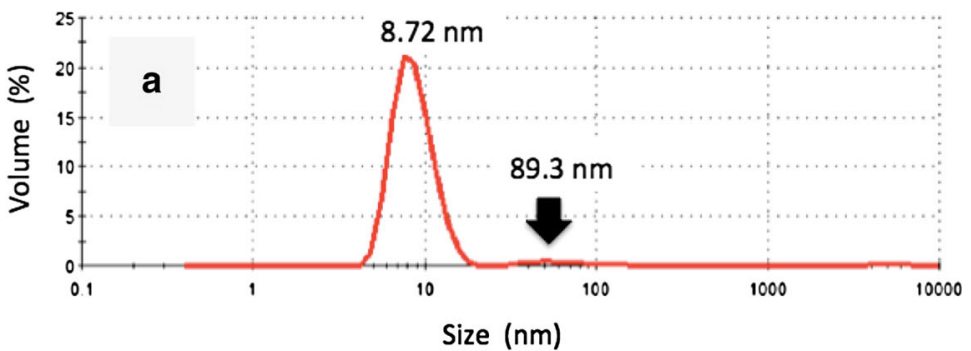

Size distribution by number

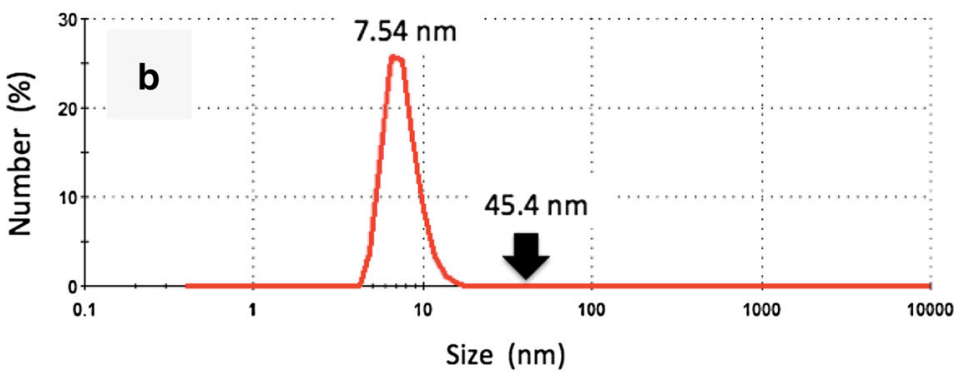

Panel II

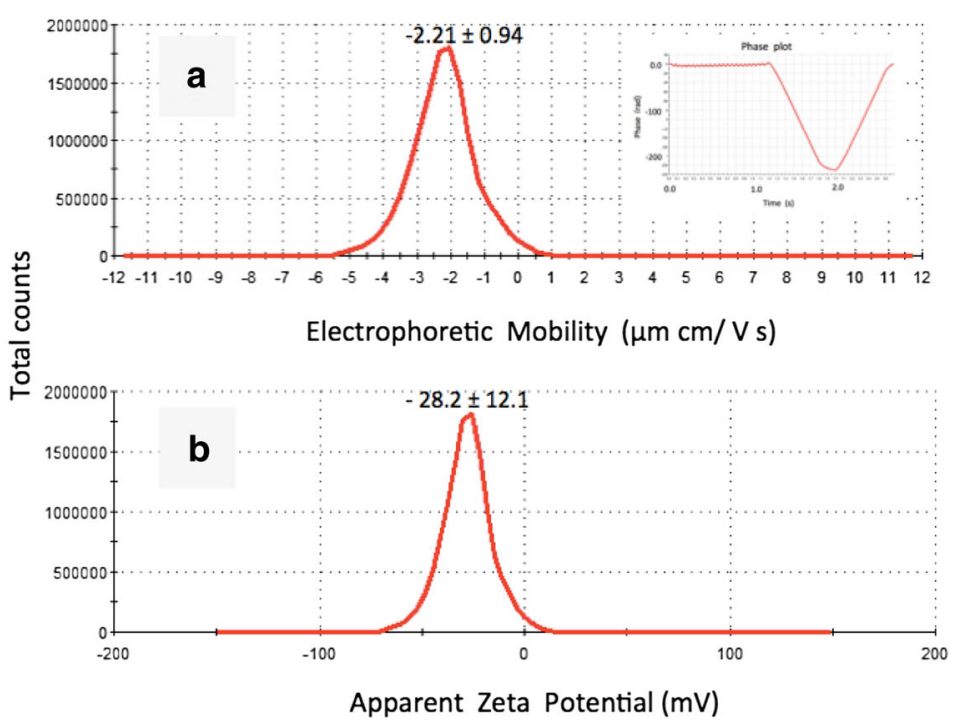

Fig. 1 AgNP characterization. Panel I: Representative distribution patterns of silver nanoparticle size by volume (a) and number (b). The measurements were performed using dynamic light scattering (DLS) method. The size value corresponds to a peak position. Black arrows indicate low, broad peaks corresponding to agglomerated particles. Panel II: Representative electrophoretic mobility (a) and zeta potential (b) distributions of silver nanoparticles obtained for hundred runs. The inset in a shows a high quality phase plot generated for this dispersion system using Laser Doppler Velocimetry (LDV). The results are presented as mean \pm SD. Panel III: Representative atomic force microscopy (AFM) imaging of DMEM medium with and without serum and with and without AgNPs incubated for $48 \mathrm{~h}$ and deposited on atomic flat mica surface. (a) AgNPs $(5 \mu \mathrm{g} / \mathrm{ml})$ suspended in a serumfree DMEM. The particles were of size from a few to about $20 \mathrm{~nm}$ (the height profile used for particle size measurements is given in the inset) and did not agglomerate. (b) DMEM with serum in the absence of AgNPs and (c) DMEM with serum in the presence of AgNPs (5 $\mu \mathrm{g} / \mathrm{ml})$. The globular complexes of approximately $10 \mathrm{~nm}$ in size were typically observed, whereas the agglomerates of the size above $100 \mathrm{~nm}$ were rarely observed. The presence of AgNPs did not substantially alter the particle size distribution. Height sensor images were obtained in the Peak Force mode. Arrows indicate nano-objects subjected to height profile analysis. Panel IV: The ability of serum proteins to bind to the surface of AgNPs to form coating (the protein corona) estimated using SDS-PAGE. Mild serum protein enrichment on the surface on AgNPs was observed. Lane M: protein marker, Lane 1: DMEM medium with $10 \%$ FBS, Lane 2: $10 \%$ FBS in PBS, Lane 3: DMEM medium with $10 \%$ FBS incubated with AgNPs $(5 \mu \mathrm{g} / \mathrm{ml})$ for $48 \mathrm{~h}$ (see "Materials and Methods" section for more details) 


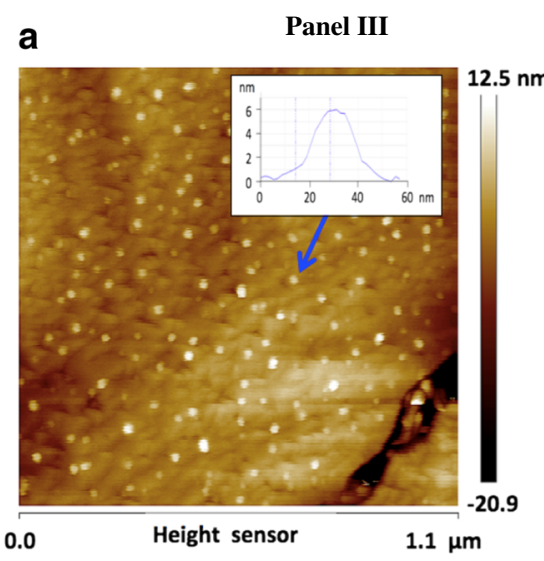

b
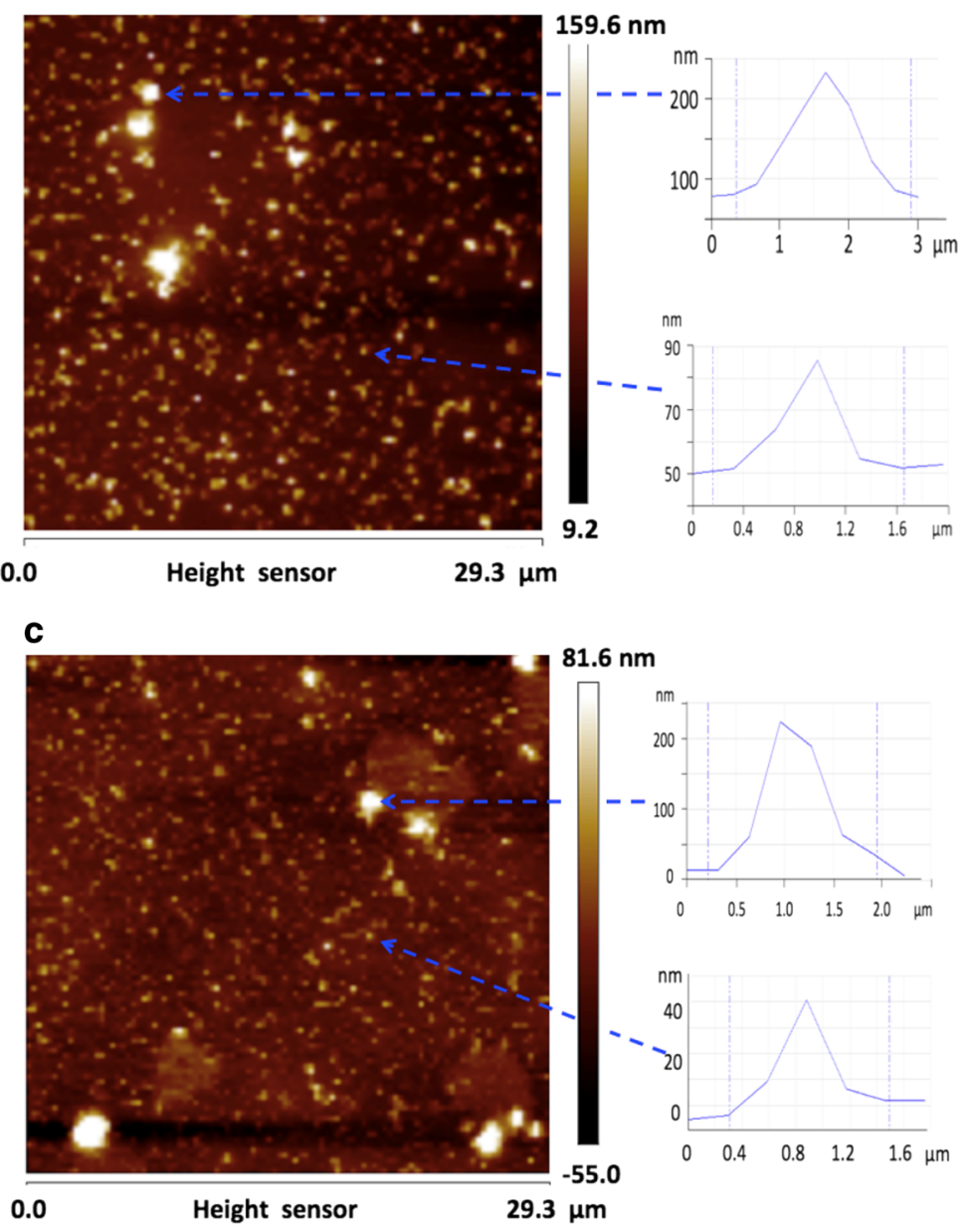

Panel IV

$\begin{array}{llll}M & 1 & 2 & 3\end{array}$

$66 \mathrm{kDa}$

$45 \mathrm{kDa}$

$36 \mathrm{kDa}$

$24 \mathrm{kDa}$

Fig. 1 (continued) 
approximately $3 \mathrm{~nm}$ to approximately $15 \mathrm{~nm}$. The zeta potential of the AgNP dispersion showed a negative value and was equal to about $-28 \mathrm{mV}$ (Fig. 1, Panel II, b). This value is close to a critical value of $-30 \mathrm{mV}$ predicting potential physical stability of the suspension. Thus, this indicates a low tendency of AgNPs to aggregation because of the occurrence of the surface electrical charge high enough to prevent particle interactions. These data are consistent with estimation of the AgNP size in the same dispersion system, which suggest the presence of a very low fraction of agglomerated particles exceeding size of $20 \mathrm{~nm}$. Moreover, AgNPs were characterized using atomic force microscopy (AFM; Fig. 1, Panel III). The particles were quite uniformly distributed and did not show a tendency to agglomerate in the DMEM medium. The size of the particles ranging from a few to $20 \mathrm{~nm}$ was consistent with that determined hydrodynamically using ZetaSizer for water suspensions and with the size of AgNPs observed by atomic force microscopy when suspended in water [36]. To elucidate whether the presence of AgNPs in serum suspension substantially favored the formation of protein agglomerates as a result of short-term incubation (48 h), we compared the AFM images of the DMEM and serum suspensions with and without AgNPs. In the suspension without serum, the nanostructures exhibiting the size from 20 to a few tens of nanometers were dominated (Fig. 1, Panel IIIa). The fraction of larger particles, around a hundred and more, occurred at much lower frequency. Representative height profiles are included on the right of the images (Fig. 1, Panel IIIa). Similar particle size distribution was observed after 48-h incubation without and with $5 \mu \mathrm{g} / \mathrm{ml} \mathrm{AgNPs}$ (Fig. 1, Panel IIIb and c). Two groups of particles could be distinguished and both fractions were represented by the particles of similar size compared to the suspension without AgNPs. Therefore, there is no evidence that short-term incubation with AgNPs in culture medium considerably affected the tendency to agglomeration. The ability of serum proteins to bind to the surface of AgNPs was also evaluated (Fig. 1, Panel IV). Serum protein enrichment was observed only when the total medium volume used $(15 \mathrm{ml})$ was concentrated and subjected to protein corona analysis (Fig. 1, Panel IV) after 48-h treatment with $5 \mu \mathrm{g} / \mathrm{ml}$ AgNPs.

HT22 mouse hippocampal cells were then subjected to AgNP treatment (1-20 $\mu \mathrm{g} / \mathrm{ml})$ for $48 \mathrm{~h}$, and AgNP-mediated cytotoxicity, changes in the cell cycle, and cell proliferation were evaluated (Fig. 2).

AgNPs caused a decrease in the number of metabolically active cells (MTT assay; Fig. 2a, left). The effect was concentration-dependent and statistically significant $\left(p<0.001\right.$; Fig. 2a). The $\mathrm{IC}_{50}$ value was estimated to be $5 \mu \mathrm{g} / \mathrm{ml}$ (Fig. 2a, left). The toxicity of $\mathrm{AgNO}_{3}$ was also considered (Fig. 2a, left). At lower concentrations (up to $5 \mu \mathrm{g} / \mathrm{ml}$ ), $\mathrm{AgNO}_{3}$ was found to be less toxic than AgNPs (Fig. 2a, left) that may suggest that $\mathrm{AgNP}$ effect differs from $\mathrm{AgNO}_{3}$ effect on HT22 cells. To further characterize the involvement of silver ions in AgNP toxicity, DMEM culture medium (with and without serum) was pretreated with AgNPs for $48 \mathrm{~h}$ to allow for silver ion release to the culture medium, centrifuged, and used as a "normal" culture medium. We were unable to observe any significant differences between pretreatment and control conditions (Fig. 2a, middle).

The involvement of serum was also assayed (Fig. 2a, right). The toxicity of $5 \mu \mathrm{g} / \mathrm{ml} \mathrm{AgNPs}$ was potentiated in a serum-free medium ( $p<0.001$; Fig. $2 \mathrm{a}$, right) that may be a result of protein corona formation-mediated effects on the uptake, fate, and toxicity of AgNPs [37, 38].

AgNPs also promoted changes in the cell cycle (Fig. 2b). After AgNP treatment, cells preferentially stayed in the G2/M phase of the cell cycle. The percentage of cells in the G2/M phase of the cell cycle increased from $8 \%$ (control conditions) to approximately $33 \%$ (treatment with $10 \mu \mathrm{g} / \mathrm{ml} \mathrm{AgNPs}$ ) $(p<0.001)$, and the level of cells in the G0-G1 phase of the cell cycle decreased from $67 \%$ (control conditions) to approximately $44 \%$ (treatment with $10 \mu \mathrm{g} / \mathrm{ml}$ AgNPs; $p<0.01$; Fig. 2b). Moreover, the percentage of cells in the $\mathrm{S}$ phase of the cell cycle slightly dropped from $25 \%$ (control conditions) to approximately $22 \%$ (treatment with $10 \mu \mathrm{g} / \mathrm{ml} \mathrm{AgNPs;}$ Fig. 2b). However, the effect was not statistically significant. AgNPs also affected cell proliferation (Fig. 2c). After 5 and $20 \mu \mathrm{g} / \mathrm{ml} \mathrm{AgNP}$ treatment, 30 and $55 \%$ of cells were unable to incorporate BrdU into their DNA, respectively, compared to control $(p<0.001$; Fig. $2 c)$.

We then asked the question of whether AgNP effects may be prolonged and may affect cytophysiology of HT22 cells after AgNP removal. A concentration reflecting the $\mathrm{IC}_{50}$ value (MTT assay), $5 \mu \mathrm{g} / \mathrm{ml}$, was selected for further analyses. HT22 cells were incubated with $5 \mu \mathrm{g} / \mathrm{ml} \mathrm{AgNPs}$ for $48 \mathrm{~h}$, washed, and cultured in AgNP-free medium for up to $144 \mathrm{~h}$ (96 h after AgNP removal), and morphology, AgNP localization, cytotoxicity, cell cycle, and cell proliferation analyses were conducted (Fig. 3).

First, HT22 cell morphology was compared after 48-h treatment and AgNP removal (Fig. 3a). AgNP treatment affected cell morphology (Fig. 3a). The cells formed clusters and the number of nucleoli was increased (Fig. 3a), whereas AgNP removal resulted in cell morphology more similar to control conditions (Fig. 3a). Intracellular localization (uptake) of AgNPs was confirmed using Nomarski microscopy (Fig. 3b). After AgNP removal, AgNPs were also observed in HT22 cells (Fig. 3b). After $5 \mu \mathrm{g} / \mathrm{ml} \mathrm{AgNP}$ removal, the number of cells was decreased compared to control ( $p<0.001$; Fig. 3c). However, when considering 48-h treatment, the cell yield was slightly increased (Fig. 3c). After $5 \mu \mathrm{g} / \mathrm{ml}$ AgNP removal, cytotoxic effects were not observed (Fig. 3d). In contrast, changes in the cell cycle and the inhibition of cell proliferation were noticed (Fig. 3e, f). The 
a
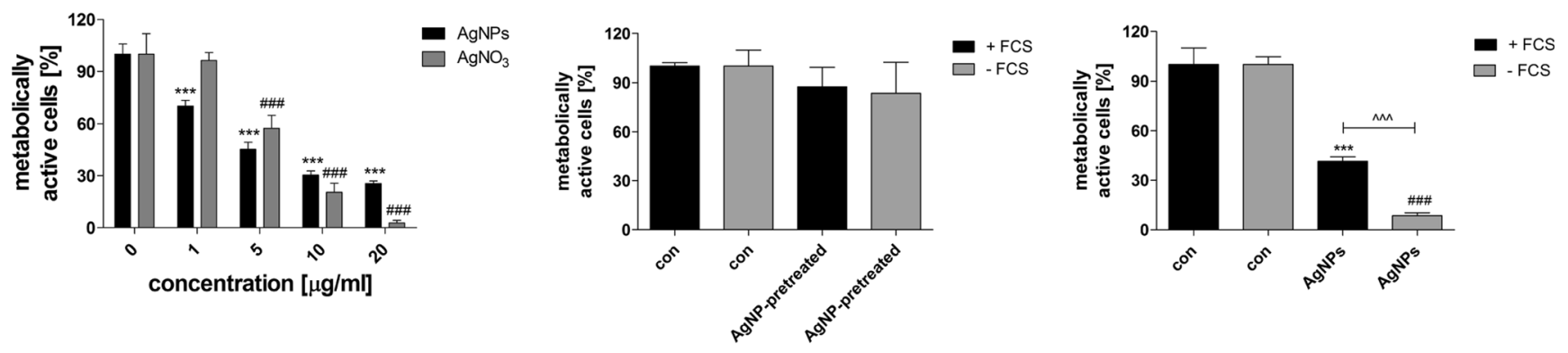

b

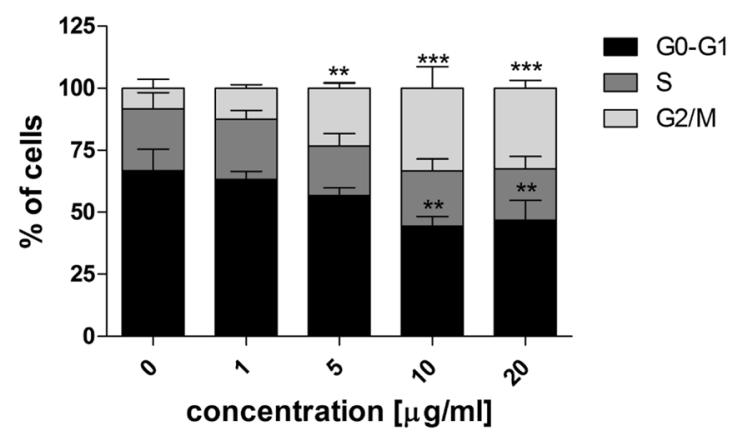

Fig. 2 AgNP-induced cell viability (a), changes in the cell cycle (b), and cell proliferation $(\mathbf{c})$. HT22 cells were treated with AgNPs $(1-20 \mu \mathrm{g} / \mathrm{ml})$ for $48 \mathrm{~h}$. a MTT assay. Metabolic activity at standard growth conditions is considered as $100 \%$. The bars indicate the SD, $n=5$, *** $p<0.001$ compared to control (ANOVA and Dunnett's a posteriori test). HT22 cells were also treated with $\mathrm{AgNO}_{3}(1-20 \mu \mathrm{g} / \mathrm{ml})$ for $48 \mathrm{~h}$ for

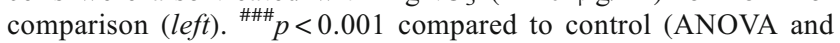
Dunnett's a posteriori test). The effect of silver ion release from AgNPs was also evaluated (middle). DMEM medium was pre-incubated with $5 \mu \mathrm{g} / \mathrm{ml} \mathrm{AgNPs}$ for $48 \mathrm{~h}$ and supernatant was used as a "normal" culture medium; con, culture in DMEM with and without serum; AgNP-pretreated, culture in AgNP-pretreated DMEM with and without serum. The effect of serum on AgNP-mediated cell viability (right).

percentage of cells in the $\mathrm{G} 2 / \mathrm{M}$ phase of the cell cycle increased from $10 \%$ (control conditions) to approximately $17 \%$ (after AgNP removal; Fig. 3e). Moreover, the percentage of cells in the $\mathrm{S}$ phase of the cell cycle dropped from $24 \%$ (control conditions) to approximately $20 \%$ (after AgNP removal; Fig. 3e). However, the effects were not statistically significant. After $5 \mu \mathrm{g} / \mathrm{ml}$ AgNP removal, $20 \%$ of cells were unable to incorporate BrdU into their DNA compared to control ( $p<0.001$; Fig. 3f).

As AgNPs may still modulate HT22 cell cycle and proliferation after their removal, we decided to evaluate if AgNP removal may also affect intracellular redox homeostasis, 53BP1 recruitment, and the levels of p53, $\mathrm{p} 21$, and lamin $\mathrm{B} 1$, and affect methylation parameters and RNA status.

The removal of $5 \mu \mathrm{g} / \mathrm{ml}$ AgNPs was accompanied by oxidative stress (Fig. 4).

A 1.6-, 2.5-, and 1.6-fold increase in intracellular ROS, total superoxide, and mitochondrial superoxide production

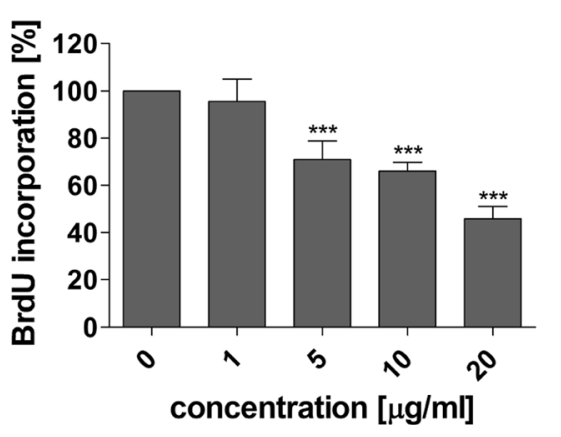

HT22 cells were incubated with $5 \mu \mathrm{g} / \mathrm{ml} \mathrm{AgNPs} \mathrm{in} \mathrm{the} \mathrm{presence} \mathrm{or} \mathrm{the}$ absence of serum in DMEM medium for $48 \mathrm{~h}$. $* * * p<0.001$ compared to control culture in complete medium, ${ }^{\# \# \#} p<0.001$ compared to control culture in a serum-free medium, ${ }^{\wedge \wedge} \wedge p<0.001$ compared to $5 \mu \mathrm{g} / \mathrm{ml}$ AgNP treatment in complete medium (ANOVA and Dunnett's a posteriori test). b Cell cycle analysis using imaging cytometry (In Cell Analyzer 2000, GE Healthcare, UK) and ImageJ software. The bars indicate the SD, $n=200, * * * p<0.001, * * p<0.01$, compared to control (ANOVA and Dunnett's a posteriori test). c Cell proliferation was estimated as the ability of cells to synthesize DNA: BrdU incorporation assay. Cell proliferation at standard growth conditions is considered as $100 \%$. The bars indicate the SD, $n=200, * * * p<0.001$ compared to control (ANOVA and Dunnett's a posteriori test)

was observed, respectively, compared to control $(p<0.01$ and $p<0.001$; Fig. 4 ).

Fig. 3 Impact of $5 \mu \mathrm{g} / \mathrm{ml} \mathrm{AgNP}$ treatment and removal on cell morphology (a), cellular localization of AgNPs (b), cell number (c), cytotoxicity (d), cell cycle (e), and cell proliferation (f). HT22 cells were treated with $5 \mu \mathrm{g} / \mathrm{ml} \mathrm{AgNPs}$ for $48 \mathrm{~h}$, AgNPs were then removed and cells were cultured for another $96 \mathrm{~h}$ (a total culture time was $144 \mathrm{~h}$ ). a Cells were inspected using inverted microscope. b AgNPs were visualized using differential interference contrast (DIC) microscopy and DNA was stained using Hoechst staining (blue). c Cell number was assessed using a Bürker chamber. The bars indicate the $\mathrm{SD}, n=3$, $* * * p<0.001$ compared to control (ANOVA and Dunnett's a posteriori test). d Cell viability was assessed using acridine orange-ethidium bromide staining. e DNA-content-based cell cycle analysis using imaging cytometry (In Cell Analyzer 2000, GE Healthcare, UK) and ImageJ software. The bars indicate the $\mathrm{SD}, n=200$. f Cell proliferation was estimated as the ability of cells to synthesize DNA: BrdU incorporation assay. Cell proliferation at standard growth conditions is considered as $100 \%$. The bars indicate the SD, $n=200, * * * p<0.001$ compared to control (ANOVA and Dunnett's a posteriori test) (color figure online) 
We also investigated AgNP-mediated formation of p53 binding protein (53BP1) foci, which are considered to be accumulated at site of double-strand breaks (DSBs) being a part of DNA repair process. The recruitment of 53BP1 was much more accented after 48-h treatment with AgNPs $(1-20 \mu \mathrm{g} / \mathrm{ml})$ than after removal of $5 \mu \mathrm{g} / \mathrm{ml} \mathrm{AgNPs}$ (Fig. 5).
After 10 and $20 \mu \mathrm{g} / \mathrm{ml} \mathrm{AgNP}$ treatment, the level of 53BP1 foci-positive cells were 30 and $50 \%$, respectively, compared to $15 \%$ level of control (Fig. 5a). However, the recruitment of 53BP1 after removal of $5 \mu \mathrm{g} / \mathrm{ml}$ AgNPs was also observed (Fig. 5b). The level of 53BP1 foci-positive cells increased threefold compared to untreated control (Fig. 5b). a

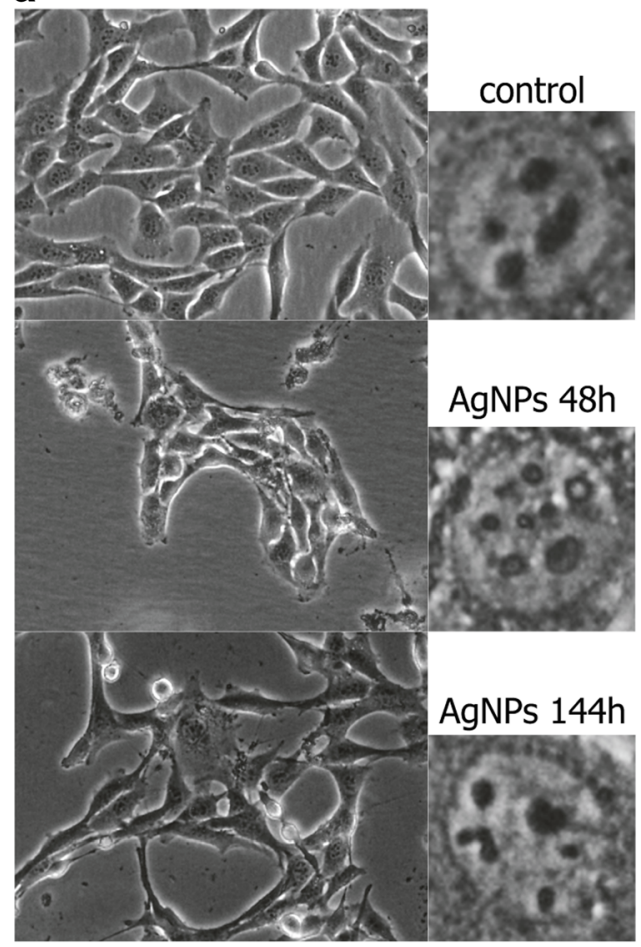

C

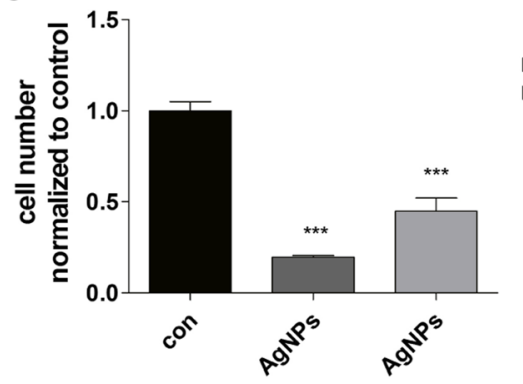

b

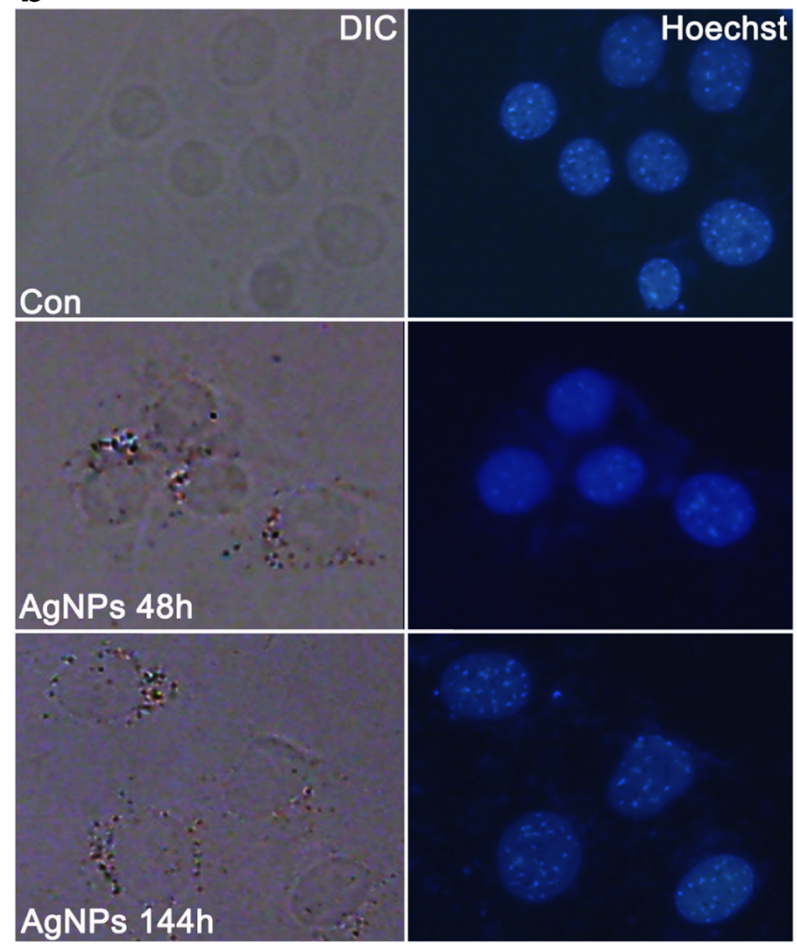

d
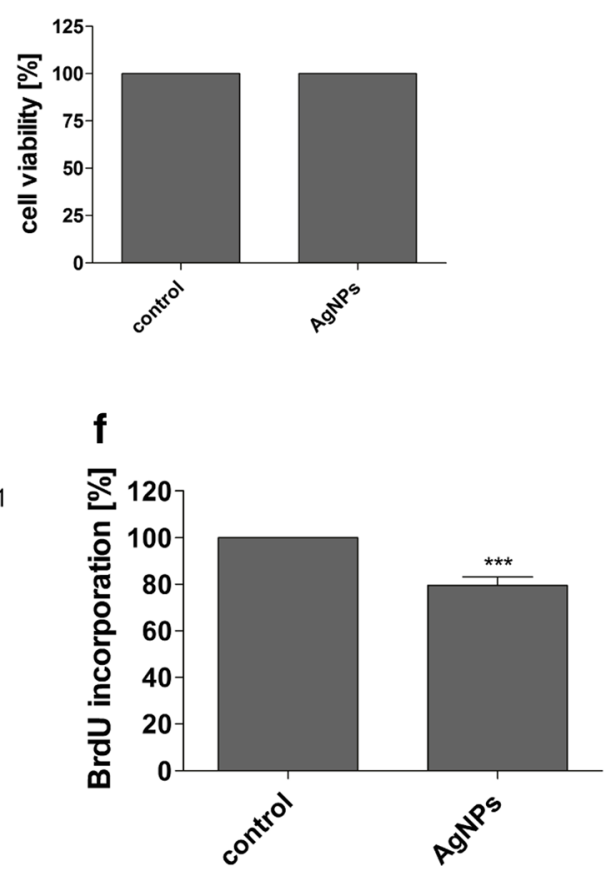


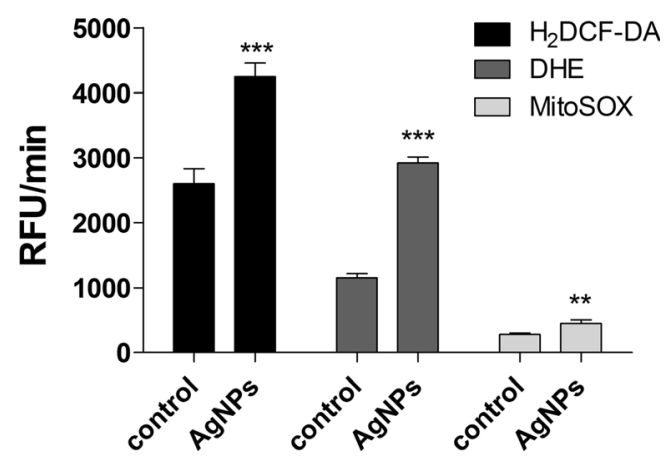

Fig. 4 AgNP-induced oxidative stress. HT22 cells were treated with $5 \mu \mathrm{g} / \mathrm{ml} \mathrm{AgNPs}$ for $48 \mathrm{~h}$, AgNPs were then removed, and cells were cultured for another $96 \mathrm{~h}$ (a total culture time was $144 \mathrm{~h}$ ). Total reactive oxygen species (ROS) production, intracellular superoxide production both total and mitochondrial were measured with $2^{\prime}, 7^{\prime}$ dichlorodihydrofluorescein diacetate $\left(\mathrm{H}_{2} \mathrm{DCF}-\mathrm{DA}\right)$, dihydroethidium, and MitoSOX ${ }^{\mathrm{TM}}$, respectively. Fluorescence intensity was monitored in a Tecan Infinite ${ }^{\circledR}$ M200 fluorescence mode microplate reader. The bars indicate the SD, $n=5, * * * p<0.001, * * p<0.01$ compared to control (ANOVA and Dunnett's a posteriori test)

After AgNP treatment, the levels of p53 and p21 were elevated (Fig. 6a), which may contribute to AgNP-mediated antiproliferative activity (Fig. 2).

Moreover, the levels of p53 and p21 remained high after AgNP removal (Fig. 6a).

AgNPs also caused a diminution in lamin B1 pools (Fig. 6a, b) that was not accompanied by changes in the nucleus structure or F-actin cytoskeleton (Fig. 6b).

Finally, AgNPs stimulated methylation changes (Figs. 6 and 7). The effects were observed both after 48-h treatment with AgNPs and after AgNP removal (Figs. 6 and 7).

AgNPs can be considered as a DNA hypermethylating agent in HT22 cells, because AgNPs induced an increase in the levels of 5-methylcytosine (5-mC), and DNA methyltransferases 1, 3a, and 3b (DNMT1, DNMT3a, and DNMT3b; Fig. 7a-d). After AgNP removal, the content of 5-mC was increased approximately $50 \%$ compared to control ( $p<0.001$; Fig. $7 \mathrm{a})$. After AgNP removal, an increase in DNMT1, DNMT3a, and DNMT3b levels was less impressive compared to increased 5-mC levels, but these effects were statistically significant $(p<0.01$ and $p<0.05$; Fig. $7 \mathrm{~b}-\mathrm{d})$.

Surprisingly, after AgNP removal, the level of DNMT2, a methyltransferase suggested to be involved in cellular stress responses, was elevated approximately $50 \%$ compared to control (Fig. 6a). As DNMT2 may have a protective role against RNA degradation [32], we evaluated RNA status after AgNP treatment and AgNP removal (Fig. 7e). The ratio of $28 \mathrm{~S} / 18 \mathrm{~S}$ rRNA was unaffected (values between 1.8 and 2.0) that may provide evidence that RNA integrity (quality) was not compromised upon AgNP stimulation (data not shown). AgNP treatment did not result in changes in RNA pools, but
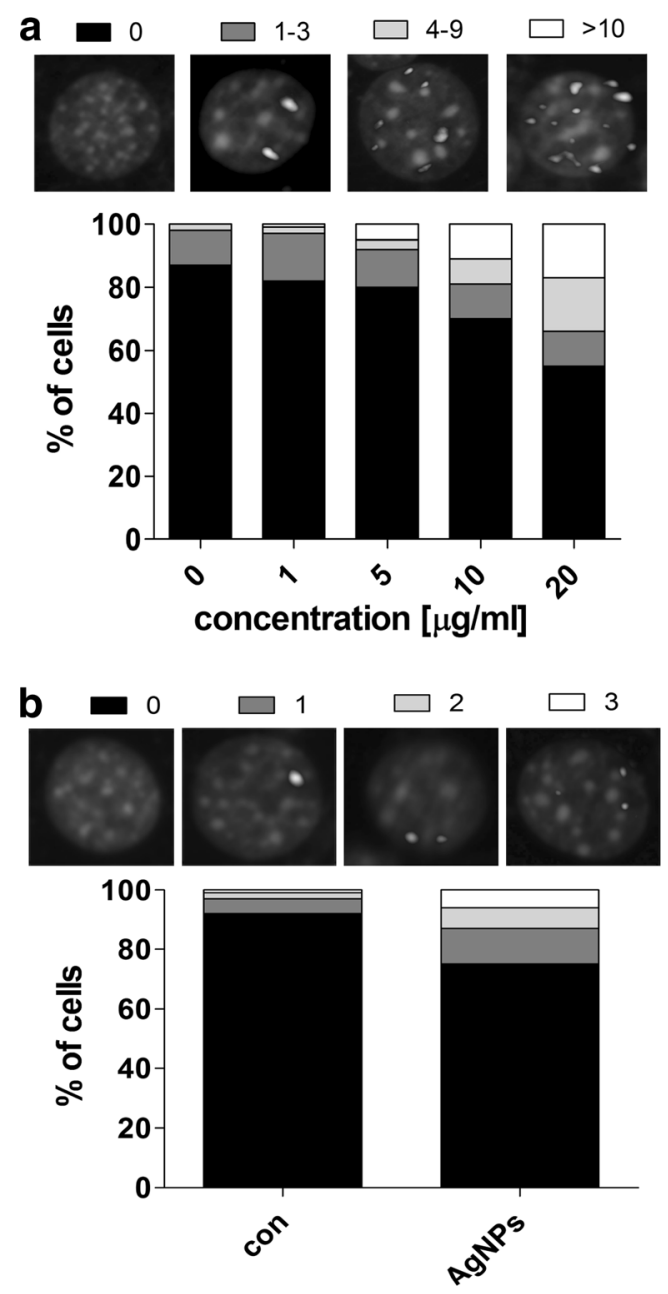

Fig. 5 AgNP-mediated 53BP1 recruitment. HT22 cells were treated with AgNPs (1-20 $\mu \mathrm{g} / \mathrm{ml}$ ) for $48 \mathrm{~h}$ (a) or HT22 cells were treated with $5 \mu \mathrm{g} / \mathrm{ml}$ AgNPs for $48 \mathrm{~h}$ and AgNPs were then removed and cells were cultured for another $96 \mathrm{~h}$ (a total culture time was $144 \mathrm{~h}$ ) (b). 53BP1 foci were revealed using 53BP1 immunostaining. Cells with $0,1-3,4-9$, and more than 10 53BP1 foci (a) or cells with $0,1,2$ and 3 53BP1 foci (b) were scored $(\%)$

after AgNP removal, RNA synthesis was diminished (Fig. 7e) that may reflect decreased transcriptional activity of AgNP-treated cells as a result of increased levels of DNMTs and subsequent global DNA hypermethylation (Fig. 7a-d).

\section{Discussion}

AgNP-mediated response in HT22 hippocampal neuronal cells was investigated; especially, attention was paid on low concentration $(5 \mu \mathrm{g} / \mathrm{ml})$ and prolonged effects of AgNPs. We showed for the first time that AgNP-induced effects retained after AgNP removal from the cell culture medium. AgNPs affected cell cycle, proliferation, redox homeostasis, response to DNA damage, and the levels of p53, p21, and lamin B1, 
a
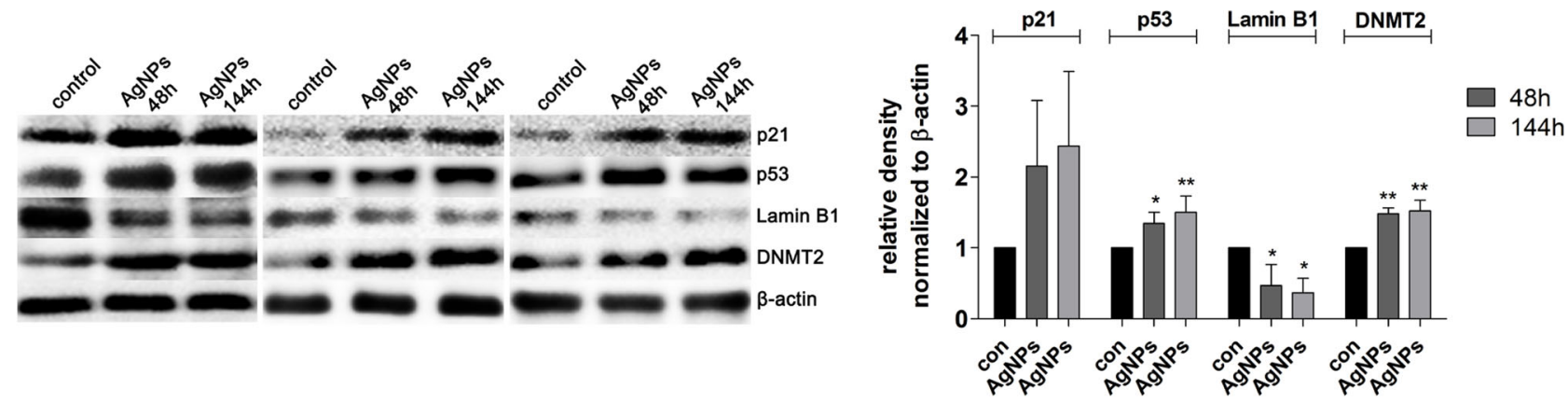

b
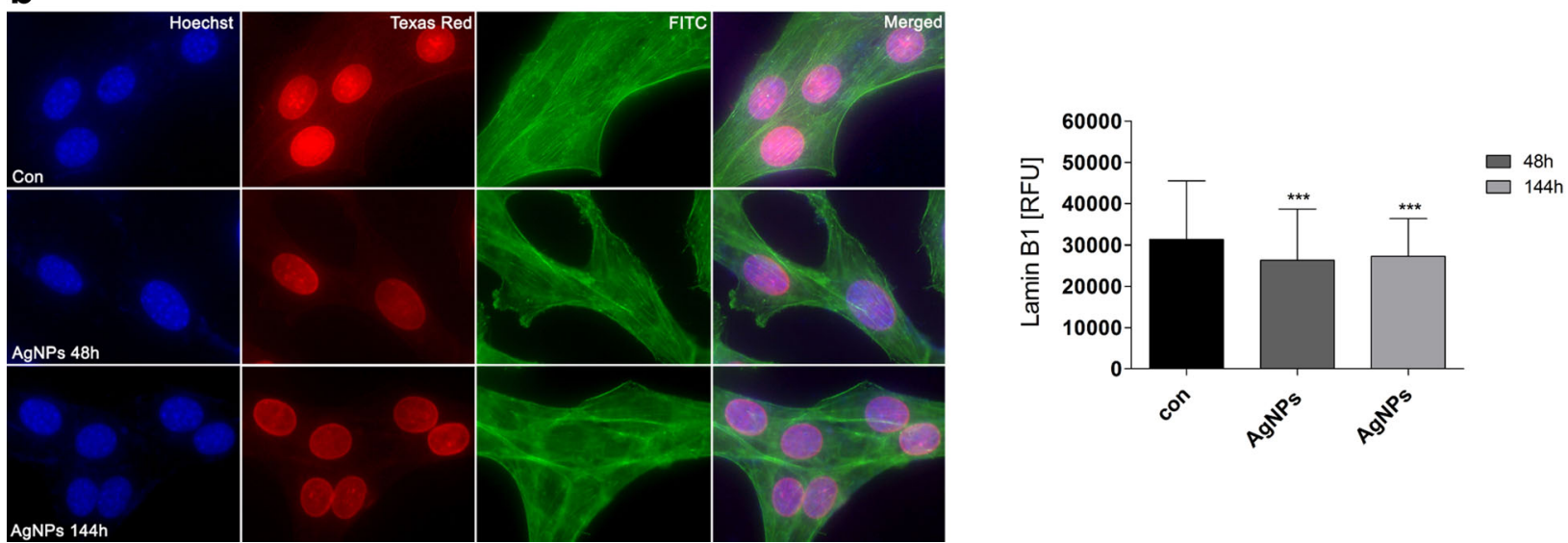

Fig. 6 AgNP-associated levels of p21, p53, lamin B1, and DNMT2. HT22 cells were treated with $5 \mu \mathrm{g} / \mathrm{ml}$ AgNPs for $48 \mathrm{~h}$ or HT22 cells were treated with $5 \mu \mathrm{g} / \mathrm{ml} \mathrm{AgNPs}$ for $48 \mathrm{~h}$ and AgNPs were then removed and cells were cultured for another $96 \mathrm{~h}$ (a total culture time was $144 \mathrm{~h}$ ). a Western blot analysis of p21, p53, lamin B1, DNMT2, and $\beta$-actin levels. Three blots representing three independent experiments are shown. The bars indicate the SD, $n=3, * * p<0.01, * p<0.05$ compared to $48 \mathrm{~h}$ control (ANOVA and Dunnett's a posteriori test). The

and promoted methylation changes that affected RNA synthesis.

AgNP toxicity is well documented [4-7]. It has been postulated and rebutted that AgNP toxicity and related biological effects may be due to silver ion toxicity [12, 14-17, 21]. In the present study, the effect of silver ion release from AgNPs was ruled out as there were no effects of AgNP-pretreated medium supernatant on HT22 cells. We found that AgNP toxicity may be affected by the presence of serum in the cell culture medium, namely, in a serum-free medium AgNP toxicity may be potentiated. Perhaps, AgNP toxicity may be modulated by the formation of a protein corona (PC) on its surface (this study). The fractions of enriched serum proteins were observed when cell culture medium was concentrated and subjected to protein corona analysis. Indeed, addition of the PC decreased uptake of AgNPs by rat lung epithelial and rat aortic endothelial cells and affected cellular toxicity via scavenger receptors [39]. Additionally, nanoparticle agglomeration in the cell culture medium may affect its toxic activities [40-43]. However, we did not observe AgNP tendency to agglomerate in the cell culture medium using AFM imaging.

data represent the relative density normalized to $\beta$-actin. b Immunofluorescence-based analysis of lamin B1 level (red). DNA was stained using Hoechst 33342 staining (blue). F-actin was labeled using Alexa Fluor® 488 Phalloidin staining (green). Lamin B1 nuclear signals are presented as relative fluorescence units (RFUs). The bars indicate the $\mathrm{SD}, n=2000, * * * p<0.001$ compared to $48 \mathrm{~h}$ control (ANOVA and Dunnett's a posteriori test) (color figure online)

The mechanisms of AgNP toxicity involve oxidative stress, DNA damage, and apoptosis that have been shown in numerous human cell lines in vitro [1, 4, 5, 8-14]. AgNP-mediated neurotoxicity has also been considered [22-26], especially that nanoparticles may not only cause adverse effects in primary organs directly exposed but also in secondary organs, such as the central nervous system (CNS).

AgNPs affected intracellular redox homeostasis by increasing reactive oxygen species (ROS) production, lipid peroxidation, and protein carbonylation, and/or decreasing the levels of reduced glutathione and the activity of antioxidant enzymes (e.g., superoxide dismutase and catalase) [4, 5, 8-14]. AgNPmediated oxidative stress and calcium dysregulation have also been reported in neuronal cells that may promote apoptotic cell death and/or neurodegeneration [22, 23, 26]. AgNPinduced apoptosis involved mitochondrial pathway as AgNP treatment resulted in cytochrome $c$ release into the cytoplasm and translocation of Bax to mitochondria in NIH3T3 fibroblast cells and human Chang liver cells [10, 13]. Moreover, AgNPs may promote alterations in the mitochondrial membrane potential (MMP) leading to abnormalities in 
a

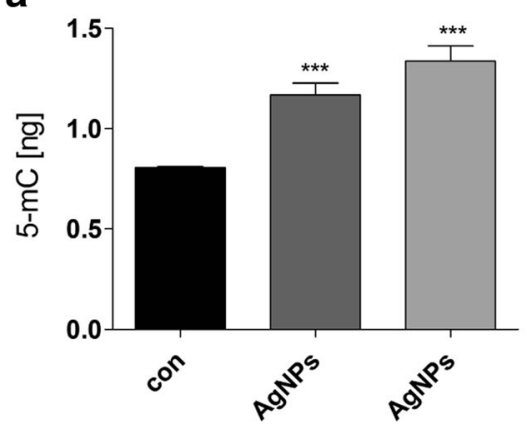

C

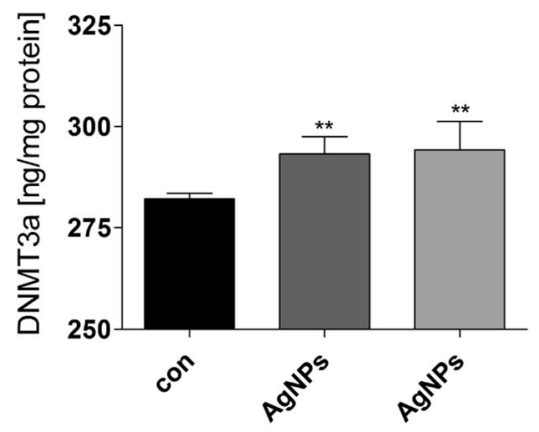

b

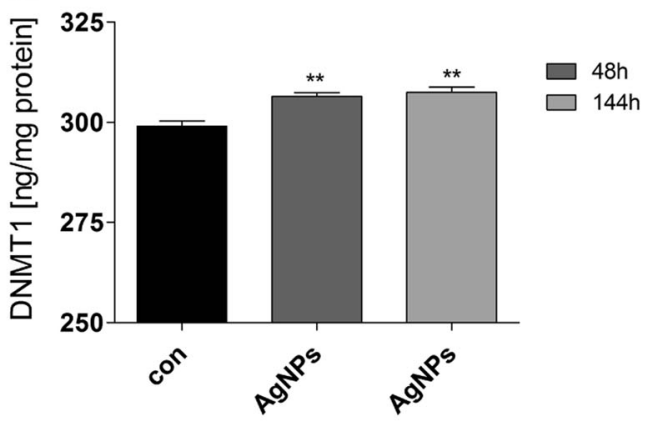

d

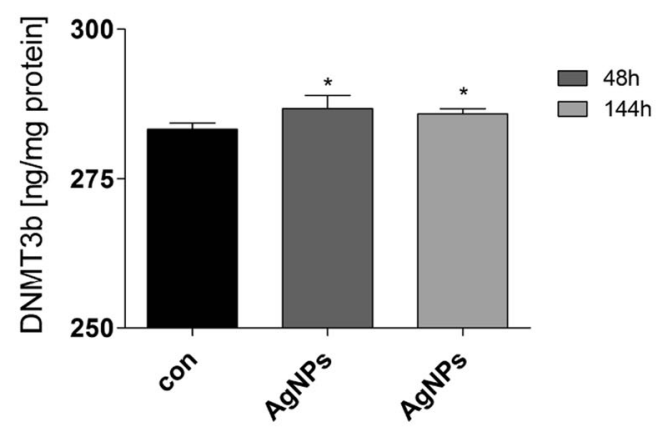

e
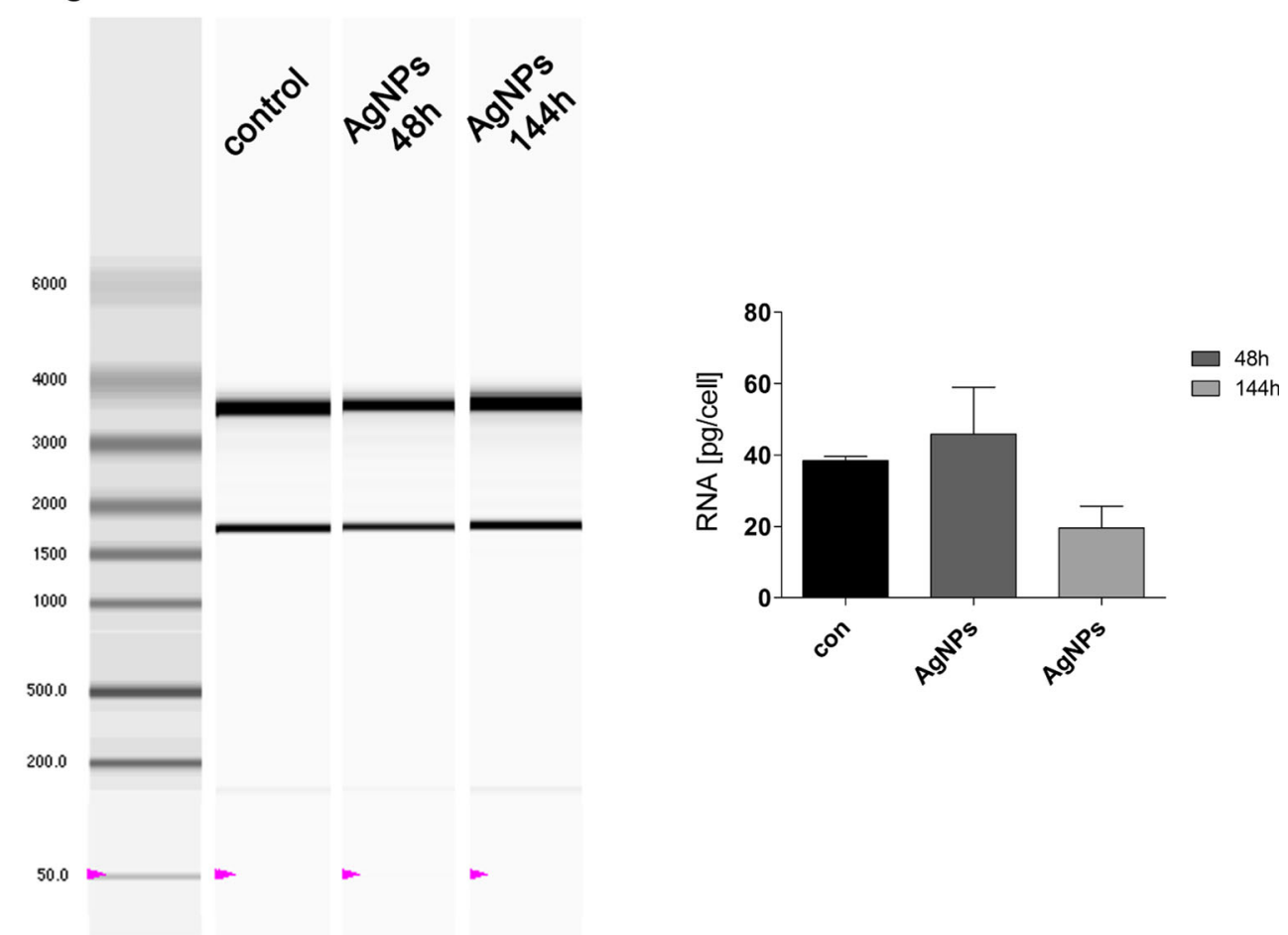

Fig. 7 AgNP-induced changes in methylation parameters and RNA status. HT22 cells were treated with $5 \mu \mathrm{g} / \mathrm{ml} \mathrm{AgNPs} \mathrm{for} 48 \mathrm{~h}$ or HT22 cells were treated with $5 \mu \mathrm{g} / \mathrm{ml} \mathrm{AgNPs}$ for $48 \mathrm{~h}$ and AgNPs were then removed and cells were cultured for another $96 \mathrm{~h}$ (a total culture time was 144 h). a 5-Methylcytosine (5-mC) level (ng) (ELISA), b DNMT1 level (ng/mg protein) (ELISA), c DNMT3a level (ng/mg protein) (ELISA), and d DNMT3b level (ng/mg protein) (ELISA). The bars indicate the SD, $n=3, * * * p<0.001, * * p<0.01, * p<0.05$ compared to $48 \mathrm{~h}$ control (ANOVA and Dunnett's a posteriori test). e RNA chip electrophoresis. RNA molecular weight marker is also shown. Total RNA (pg) is calculated per cell. The bars indicate the $\mathrm{SD}, n=3$ 
physiological functions of mitochondria, which are common during stress-induced apoptotic cell death $[11,13]$. AgNPinduced oxidative stress may also stimulate genotoxic events. Indeed, AgNP treatment resulted in DNA adducts, DNA breaks, oxidative DNA damage (increased 8-oxoguanine level), and micronuclei production [4, 13, 44-47]. AgNPs also decreased 8-oxoguanine DNA glycosylase 1 (OGG1, DNA repair enzyme that recognizes and excises 8-oxoguanine) mRNA and protein expression, resulting in decreased OGG1 activity [44]. Thus, decreased OGG1 activity in AgNP-treated cells led to increased 8-oxoguanine levels [44]. Surprisingly, HT22 cells manifested DNA damage response (53BP1 recruitment) even after AgNP removal from the cell culture medium, which suggest that AgNPs may also promote genotoxic effects (e.g., DNA double strand breaks) in these cells. Under DNA double-strand break (DSB)-promoting conditions, a complex cellular response is activated, which enables to promote DNA repair and maintain genome integrity [48], and 53BP1, p53 binding protein, is recruited to sites of DNA damage due to methylation-state-specific recognition of histone H4-K20 by 53BP1 [49]. Perhaps elevated levels of p53 and p21 are a part of HT22 cell response to DNA damage promoting conditions (AgNP treatment) and may account for observed antiproliferative activity of AgNPs in these cells to allow time for DNA repair.

AgNPs also decreased the levels of lamin B1, but this did not significantly affect the structure of nucleus of a HT22 cell. We have previously shown that diamond, silica, and silver nanoparticles may promote a diminution in lamin B1 pools in different cell lines both normal and cancer cells that is a part of telomere-focused adaptive response [36]. More recently, the effects of cobalt chrome $(\mathrm{CoCr})$ nanoparticles on nuclear morphology in human fibroblasts were studied [50]. Nano$\mathrm{CoCr}$ treatment resulted in oxidative-stress-mediated loss of mature lamin B1 [50]. Mitochondrial ROS were implicated in damage to lamin B1, increased incidence of micronuclei, and misshapen nuclei [50]. Downregulation of lamin B1 may also modulate the expression of antioxidant proteins and subsequent gene expression either through p53 or Oct-1 [51, 52]. Moreover, nuclear lamins as a ROS sink were suggested to be mediators of oxidative stress [53].

As actin cytoskeleton may be disrupted by the action of sublethal concentrations of AgNPs $(0.1-1 \mu \mathrm{g} / \mathrm{ml})$ in cultured adult neural stem cells [27], we decided to evaluate if $5 \mu \mathrm{g} / \mathrm{ml} \mathrm{AgNP}$ treatment and then AgNP removal may modulate actin cytoskeleton dynamics in HT22 cells. F-actin cytoskeleton was unaffected upon AgNP stimulation (this study). At higher concentration used (up to $50 \mu \mathrm{g} / \mathrm{ml}$ ), AgNPs disrupted filamentous actin, $\beta$-tubulin, and synaptic machinery in cultured cortical neurons [54]. The authors also concluded that associated disruption in neurogenesis may contribute to documented deficits in brain function following AgNP exposure [27, 54].
Epigenetics, heritable modifications that alter gene expression levels without resulting from direct changes in the primary DNA sequence, is implicated in both physiological and pathophysiological processes, such as development, cell proliferation and differentiation, genetic imprinting, $\mathrm{X}$ chromosome inactivation, maintenance of chromatin structure, tumor progression, cellular senescence, and organism aging [55-59]. In mammals, the main epigenetic mechanisms for gene regulation are DNA methylation, histone tail modifications (acetylation, phosphorylation, methylation), and microRNA (miRNA)-mediated mechanisms [60, 61]. Gene silencing is a result of DNA hypermethylation, whereas DNA hypomethylation activates transcription. DNA methyltransferases (DNMTs) catalyze the transfer of a methyl group from Sadenosylmethionine (SAM) to cytosine within $\mathrm{CpG}$ sequences to form 5-methylcytosine (5-mC) [62]. It is widely accepted that DNMT1 is involved in the maintenance of DNA methylation patterns during development and cell division, whereas DNMT3a and DNMT3b are the de novo methyltransferases $[63,64]$. The role of DNMT2 is more enigmatic, but it may participate in the methylation of transfer RNA molecules [65]. We showed that AgNPs may affect HT22 cell epigenome by increasing the levels of 5-mC, DNMT1, DNMT3a, and DNMT3b and acting as a DNA hypermethylating agent. Data on epigenetic properties of engineered nanomaterials, especially DNA-methylationbased effects, are limited [66], and published results on AgNP-mediated changes in DNA methylation patterns are unavailable. There are two papers on nano- $\mathrm{SiO}_{2}$-induced changes in global and loci-specific DNA methylation [67, 68]. Nano- $\mathrm{SiO}_{2}$ promoted global DNA hypomethylation (a decrease in 5-mC level), which was accompanied by decreased DNMT1 and DNMT3a mRNA and protein levels in $\mathrm{HaCaT}$ cells [67]. Moreover, nano- $\mathrm{SiO}_{2}$ caused PARP-1 hypermethylation and $P A R P-1$ mRNA repression affecting DNA damage repair process in $\mathrm{HaCaT}$ cell line [68]. In contrast, AgNPs were found to be a modulator of microRNA profiles in Jurkat T cells [21]. An integrated analysis of mRNA and miRNA expression revealed that the expression of hsa-miR-219-5p was negatively correlated with the expression of metallothionein $1 \mathrm{~F}$ (MT1F) and tribbles homolog 3 (TRIB3), and epigenetic mechanism was suggested to be involved in the toxicity of AgNPs in Jurkat T cells [21].

AgNPs also induced DNMT2 protein expression, which may be considered as a part of stress response. The role of DNMT2 in both DNA methylation and RNA methylation has been proposed [64, 69, 70]. DNA methyltransferase activity of human DNMT2 and Drosophila Dnmt2 has been reported [71, 72]. Moreover, a highly specific tRNA ${ }^{\text {Asp }}$ methyltransferase activity of DNMT2 has been postulated and rebutted $[65,73]$. Regardless of the mechanism involved, DNMT2 is implicated in the protection against cellular stresses, especially oxidative stress, in different biological systems [74-76]. More recently, 
DNMT2 was found to be upregulated in HeLa cells upon treatment with nanodiamonds, which contributed to RNA stabilization and conferred stress resistance after nanodiamond treatment [32]. Both stimulations - nanodiamond [32] and AgNP (this study) treatments - resulted in oxidative stress in HeLa and HT22 cells, respectively, and response to imbalanced redox homeostasis may involve DNMT2-based protective response against RNA degradation. Indeed, after AgNP treatment, RNA integrity was not compromised.

In conclusion, we showed for the first time that AgNPs may modulate HT22 cell proliferation, DNA damage response, and epigenome acting as a DNA hypermethylating agent. Thus, AgNPs may promote epigenetic dysregulation, which may have long-term effects on gene expression re-programming. Moreover, AgNP-induced effects may also be manifested at the epigenomic level. As human exposure to nanomaterials is rapidly increasing, it seems worthwhile to study in detail the subsequent physiological effects of AgNP-mediated epigenetic changes in biological systems including neuronal cells and tissue.

Acknowledgments We are indebted to Prof. Michal Wozniak and Dr. Magdalena Gorska (Medical University of Gdansk, Gdansk, Poland) for sharing with us HT22 mouse hippocampal neuronal cell line. This study was supported by the Polish Ministry of Science and Higher Education within the Operational Program - Innovative Economy 2007-2013 ("Generation of the Future," 19/POIG/GP/2013). Jennifer Mytych is a student of Biotechnology at University of Rzeszow, Poland.

\section{Compliance with ethical standards}

Conflict of interest None declared

Open Access This article is distributed under the terms of the Creative Commons Attribution 4.0 International License (http:// creativecommons.org/licenses/by/4.0/), which permits unrestricted use, distribution, and reproduction in any medium, provided you give appropriate credit to the original author(s) and the source, provide a link to the Creative Commons license, and indicate if changes were made.

\section{References}

1. Ahamed M, Alsalhi MS, Siddiqui MK (2010) Silver nanoparticle applications and human health. Clin Chim Acta 411(23-24):18411848

2. Kim JS, Kuk E, Yu KN, Kim JH, Park SJ, Lee HJ, Kim SH, Park YK et al (2007) Antimicrobial effects of silver nanoparticles. Nanomedicine 3(1):95-101

3. Chen X, Schluesener HJ (2008) Nanosilver: a nanoproduct in medical application. Toxicol Lett 176(1):1-12

4. Foldbjerg R, Dang DA, Autrup H (2011) Cytotoxicity and genotoxicity of silver nanoparticles in the human lung cancer cell line, A549. Arch Toxicol 85(7):743-750

5. Foldbjerg R, Olesen P, Hougaard M, Dang DA, Hoffmann HJ, Autrup H (2009) PVP-coated silver nanoparticles and silver ions induce reactive oxygen species, apoptosis and necrosis in THP-1 monocytes. Toxicol Lett 190(2):156-162

6. Bilberg K, Hovgaard MB, Besenbacher F, Baatrup E (2012) In vivo toxicity of silver nanoparticles and silver ions in zebrafish (Danio rerio). J Toxicol 2012:293784

7. Kawata K, Osawa M, Okabe S (2009) In vitro toxicity of silver nanoparticles at noncytotoxic doses to HepG2 human hepatoma cells. Environ Sci Technol 43(15):6046-6051

8. Arora S, Jain J, Rajwade JM, Paknikar KM (2008) Cellular responses induced by silver nanoparticles: in vitro studies. Toxicol Lett 179(2):93-100

9. Miethling-Graff R, Rumpker R, Richter M, Verano-Braga T, Kjeldsen F, Brewer J, Hoyland J, Rubahn HG et al (2014) Exposure to silver nanoparticles induces size- and dose-dependent oxidative stress and cytotoxicity in human colon carcinoma cells. Toxicol In Vitro 28(7):1280-1289

10. Hsin YH, Chen CF, Huang S, Shih TS, Lai PS, Chueh PJ (2008) The apoptotic effect of nanosilver is mediated by a ROS- and JNKdependent mechanism involving the mitochondrial pathway in NIH3T3 cells. Toxicol Lett 179(3):130-139

11. Hussain SM, Hess KL, Gearhart JM, Geiss KT, Schlager JJ (2005) In vitro toxicity of nanoparticles in BRL 3A rat liver cells. Toxicol In Vitro 19(7):975-983

12. Kim S, Choi JE, Choi J, Chung KH, Park K, Yi J, Ryu DY (2009) Oxidative stress-dependent toxicity of silver nanoparticles in human hepatoma cells. Toxicol In Vitro 23(6):1076-1084

13. Piao MJ, Kang KA, Lee IK, Kim HS, Kim S, Choi JY, Choi J, Hyun JW (2011) Silver nanoparticles induce oxidative cell damage in human liver cells through inhibition of reduced glutathione and induction of mitochondria-involved apoptosis. Toxicol Lett 201(1):92-100

14. Singh RP, Ramarao P (2012) Cellular uptake, intracellular trafficking and cytotoxicity of silver nanoparticles. Toxicol Lett 213(2): 249-259

15. Park EJ, Yi J, Kim Y, Choi K, Park K (2010) Silver nanoparticles induce cytotoxicity by a Trojan-horse type mechanism. Toxicol In Vitro 24(3):872-878

16. Beer C, Foldbjerg R, Hayashi Y, Sutherland DS, Autrup H (2012) Toxicity of silver nanoparticles - nanoparticle or silver ion? Toxicol Lett 208(3):286-292

17. Verano-Braga T, Miethling-Graff R, Wojdyla K, RogowskaWrzesinska A, Brewer JR, Erdmann H, Kjeldsen F (2014) Insights into the cellular response triggered by silver nanoparticles using quantitative proteomics. ACS Nano 8(3):2161-2175

18. Foldbjerg R, Irving ES, Hayashi Y, Sutherland DS, Thorsen K, Autrup H, Beer C (2012) Global gene expression profiling of human lung epithelial cells after exposure to nanosilver. Toxicol Sci 130(1):145-157

19. Xu L, Li X, Takemura T, Hanagata N, Wu G, Chou LL (2012) Genotoxicity and molecular response of silver nanoparticle (NP)based hydrogel. J Nanobiotechnol 10:16

20. Asharani P, Sethu S, Lim HK, Balaji G, Valiyaveettil S, Hande MP (2012) Differential regulation of intracellular factors mediating cell cycle, DNA repair and inflammation following exposure to silver nanoparticles in human cells. Genome Integr 3(1):2

21. Eom HJ, Chatterjee N, Lee J, Choi J (2014) Integrated mRNA and micro RNA profiling reveals epigenetic mechanism of differential sensitivity of Jurkat T cells to AgNPs and Ag ions. Toxicol Lett 229(1):311-318

22. Hussain SM, Javorina AK, Schrand AM, Duhart HM, Ali SF, Schlager JJ (2006) The interaction of manganese nanoparticles with PC-12 cells induces dopamine depletion. Toxicol Sci 92(2):456463

23. Wang J, Rahman MF, Duhart HM, Newport GD, Patterson TA, Murdock RC, Hussain SM, Schlager JJ et al (2009) Expression changes of dopaminergic system-related genes in PC12 cells 
induced by manganese, silver, or copper nanoparticles. Neurotoxicology 30(6):926-933

24. Soderstjerna E, Johansson F, Klefbohm B, Englund Johansson U (2013) Gold- and silver nanoparticles affect the growth characteristics of human embryonic neural precursor cells. PLoS One 8(3): e58211

25. Haase A, Rott S, Mantion A, Graf P, Plendl J, Thunemann AF, Meier WP, Taubert A et al (2012) Effects of silver nanoparticles on primary mixed neural cell cultures: uptake, oxidative stress and acute calcium responses. Toxicol Sci 126(2):457-468

26. Zieminska E, Stafiej A, Struzynska L (2014) The role of the glutamatergic NMDA receptor in nanosilver-evoked neurotoxicity in primary cultures of cerebellar granule cells. Toxicology 315:38-48

27. Cooper RJ, Spitzer N (2015) Silver nanoparticles at sublethal concentrations disrupt cytoskeleton and neurite dynamics in cultured adult neural stem cells. Neurotoxicology 48:231-238

28. Sagara Y, Schubert D (1998) The activation of metabotropic glutamate receptors protects nerve cells from oxidative stress. J Neurosci 18(17):6662-6671

29. Albrecht P, Lewerenz J, Dittmer S, Noack R, Maher P, Methner A (2010) Mechanisms of oxidative glutamate toxicity: the glutamate/ cystine antiporter system $\mathrm{xc}$ - as a neuroprotective drug target. CNS Neurol Disord Drug Targets 9(3):373-382

30. Lewerenz J, Letz J, Methner A (2003) Activation of stimulatory heterotrimeric $\mathrm{G}$ proteins increases glutathione and protects neuronal cells against oxidative stress. J Neurochem 87(2):522-531

31. van Leyen K, Arai K, Jin G, Kenyon V, Gerstner B, Rosenberg PA, Holman TR, Lo EH (2008) Novel lipoxygenase inhibitors as neuroprotective reagents. J Neurosci Res 86(4):904-909

32. Mytych J, Lewinska A, Bielak-Zmijewska A, Grabowska W, Zebrowski J, Wnuk M (2014) Nanodiamond-mediated impairment of nucleolar activity is accompanied by oxidative stress and DNMT2 upregulation in human cervical carcinoma cells. Chem Biol Interact 220C:51-63

33. Lewinska A, Wnuk M, Grabowska W, Zabek T, Semik E, Sikora E, Bielak-Zmijewska A (2015) Curcumin induces oxidationdependent cell cycle arrest mediated by SIRT7 inhibition of rDNA transcription in human aortic smooth muscle cells. Toxicol Lett 233(3):227-238

34. Lewinska A, Adamczyk J, Pajak J, Stoklosa S, Kubis B, Pastuszek P, Slota E, Wnuk M (2014) Curcumin-mediated decrease in the expression of nucleolar organizer regions in cervical cancer (HeLa) cells. Mutat Res 771:43-52

35. Dworak N, Wnuk M, Zebrowski J, Bartosz G, Lewinska A (2014) Genotoxic and mutagenic activity of diamond nanoparticles in human peripheral lymphocytes in vitro. Carbon 68:763-776

36. Mytych J, Pacyk K, Pepek M, Zebrowski J, Lewinska A, Wnuk M (2015) Nanoparticle-mediated decrease of lamin B1 pools promotes a TRF protein-based adaptive response in cultured cells. Biomaterials 53:107-116

37. Lundqvist M, Stigler J, Elia G, Lynch I, Cedervall T, Dawson KA (2008) Nanoparticle size and surface properties determine the protein corona with possible implications for biological impacts. Proc Natl Acad Sci U S A 105(38):14265-14270

38. Lynch I, Dawson KA (2008) Protein-nanoparticle interactions. Nano Today 3(1-2):40-47

39. Shannahan JH, Podila R, Aldossari AA, Emerson H, Powell BA, Ke PC, Rao AM, Brown JM (2015) Formation of a protein corona on silver nanoparticles mediates cellular toxicity via scavenger receptors. Toxicol Sci 143(1):136-146

40. Arora S, Jain J, Rajwade JM, Paknikar KM (2009) Interactions of silver nanoparticles with primary mouse fibroblasts and liver cells. Toxicol Appl Pharmacol 236(3):310-318

41. Murdock RC, Braydich-Stolle L, Schrand AM, Schlager JJ, Hussain SM (2008) Characterization of nanomaterial dispersion in solution prior to in vitro exposure using dynamic light scattering technique. Toxicol Sci 101(2):239-253

42. Ahamed M, Karns M, Goodson M, Rowe J, Hussain SM, Schlager JJ, Hong Y (2008) DNA damage response to different surface chemistry of silver nanoparticles in mammalian cells. Toxicol Appl Pharmacol 233(3):404-410

43. Foucaud L, Wilson MR, Brown DM, Stone V (2007) Measurement of reactive species production by nanoparticles prepared in biologically relevant media. Toxicol Lett 174(1-3):1-9

44. Piao MJ, Kim KC, Choi JY, Choi J, Hyun JW (2011) Silver nanoparticles down-regulate Nrf2-mediated 8-oxoguanine DNA glycosylase 1 through inactivation of extracellular regulated kinase and protein kinase B in human Chang liver cells. Toxicol Lett 207(2):143-148

45. Hackenberg S, Scherzed A, Kessler M, Hummel S, Technau A, Froelich K, Ginzkey C, Koehler C et al (2011) Silver nanoparticles: evaluation of DNA damage, toxicity and functional impairment in human mesenchymal stem cells. Toxicol Lett 201(1):27-33

46. Li Y, Chen DH, Yan J, Chen Y, Mittelstaedt RA, Zhang Y, Biris AS, Heflich RH et al (2012) Genotoxicity of silver nanoparticles evaluated using the Ames test and in vitro micronucleus assay. Mutat Res 745(1-2):4-10

47. Kim HR, Kim MJ, Lee SY, Oh SM, Chung KH (2011) Genotoxic effects of silver nanoparticles stimulated by oxidative stress in human normal bronchial epithelial (BEAS-2B) cells. Mutat Res 726(2):129-135

48. Stewart GS (2009) Solving the RIDDLE of 53BP1 recruitment to sites of damage. Cell Cycle 8(10):1532-1538

49. Botuyan MV, Lee J, Ward IM, Kim JE, Thompson JR, Chen J, Mer G (2006) Structural basis for the methylation state-specific recognition of histone $\mathrm{H} 4-\mathrm{K} 20$ by 53BP1 and $\mathrm{Crb} 2$ in DNA repair. Cell 127(7):1361-1373

50. Raghunathan VK, Devey M, Hawkins S, Hails L, Davis SA, Mann S, Chang IT, Ingham E et al (2013) Influence of particle size and reactive oxygen species on cobalt chrome nanoparticle-mediated genotoxicity. Biomaterials 34(14):3559-3570

51. Shimi T, Butin-Israeli V, Adam SA, Hamanaka RB, Goldman AE, Lucas CA, Shumaker DK, Kosak ST et al (2011) The role of nuclear lamin B1 in cell proliferation and senescence. Genes Dev 25(24): 2579-2593

52. Malhas AN, Lee CF, Vaux DJ (2009) Lamin B1 controls oxidative stress responses via Oct-1. J Cell Biol 184(1):45-55

53. Sieprath T, Darwiche R, De Vos WH (2012) Lamins as mediators of oxidative stress. Biochem Biophys Res Commun 421(4):635-639

54. Xu F, Piett C, Farkas S, Qazzaz M, Syed NI (2013) Silver nanoparticles (AgNPs) cause degeneration of cytoskeleton and disrupt synaptic machinery of cultured cortical neurons. Mol Brain 6:29

55. Klein G (2005) Epigenetics: surveillance team against cancer. Nature 434(7030): 150

56. Richardson B (2003) Impact of aging on DNA methylation. Ageing Res Rev 2(3):245-261

57. Jones PA, Baylin SB (2002) The fundamental role of epigenetic events in cancer. Nat Rev Genet 3(6):415-428

58. Issa JP (2003) Age-related epigenetic changes and the immune system. Clin Immunol 109(1):103-108

59. Lu Q, Qiu X, Hu N, Wen H, Su Y, Richardson BC (2006) Epigenetics, disease, and therapeutic interventions. Ageing Res Rev 5(4):449-467

60. Das PM, Singal R (2004) DNA methylation and cancer. J Clin Oncol 22(22):4632-4642

61. Jenuwein T, Allis CD (2001) Translating the histone code. Science 293(5532):1074-1080

62. Robertson KD (2002) DNA methylation and chromatin unraveling the tangled web. Oncogene 21(35):5361-5379

63. Bestor T, Laudano A, Mattaliano R, Ingram V (1988) Cloning and sequencing of a cDNA encoding DNA methyltransferase of mouse 
cells. The carboxyl-terminal domain of the mammalian enzymes is related to bacterial restriction methyltransferases. J Mol Biol 203(4):971-983

64. Okano M, Xie S, Li E (1998) Cloning and characterization of a family of novel mammalian DNA (cytosine-5) methyltransferases. Nat Genet 19(3):219-220

65. Goll MG, Kirpekar F, Maggert KA, Yoder JA, Hsieh CL, Zhang X, Golic KG, Jacobsen SE et al (2006) Methylation of tRNAAsp by the DNA methyltransferase homolog Dnmt2. Science 311(5759): 395-398

66. Stoccoro A, Karlsson HL, Coppede F, Migliore L (2013) Epigenetic effects of nano-sized materials. Toxicology 313(1):3-14

67. Gong C, Tao G, Yang L, Liu J, Liu Q, Zhuang Z (2010) SiO(2) nanoparticles induce global genomic hypomethylation in $\mathrm{HaCaT}$ cells. Biochem Biophys Res Commun 397(3):397-400

68. Gong C, Tao G, Yang L, Liu J, Liu Q, Li W, Zhuang Z (2012) Methylation of PARP-1 promoter involved in the regulation of nano-SiO2-induced decrease of PARP-1 mRNA expression. Toxicol Lett 209(3):264-269

69. Yoder JA, Bestor TH (1998) A candidate mammalian DNA methyltransferase related to pmtlp of fission yeast. Hum Mol Genet 7(2):279-284
70. Schaefer M, Lyko F (2010) Solving the Dnmt2 enigma. Chromosoma 119(1):35-40

71. Lyko F, Ramsahoye BH, Jaenisch R (2000) DNA methylation in Drosophila melanogaster. Nature 408(6812):538-540

72. Hermann A, Schmitt S, Jeltsch A (2003) The human Dnmt2 has residual DNA-(cytosine-C5) methyltransferase activity. J Biol Chem 278(34):31717-31721

73. Schaefer M, Pollex T, Hanna K, Tuorto F, Meusburger M, Helm M, Lyko F (2010) RNA methylation by Dnmt2 protects transfer RNAs against stress-induced cleavage. Genes Dev 24(15):1590-1595

74. Lin MJ, Tang LY, Reddy MN, Shen CK (2005) DNA methyltransferase gene dDnmt2 and longevity of Drosophila. J Biol Chem 280(2):861-864

75. Fisher O, Siman-Tov R, Ankri S (2006) Pleiotropic phenotype in Entamoeba histolytica overexpressing DNA methyltransferase (Ehmeth). Mol Biochem Parasitol 147(1):48-54

76. Thiagarajan D, Dev RR, Khosla S (2011) The DNA methyltranferase Dnmt2 participates in RNA processing during cellular stress. Epigenetics 6(1):103-113 